\title{
Kernos
}

Revue internationale et pluridisciplinaire de religion grecque antique

$27 \mid 2014$

Varia

\section{The Pasikrata Sanctuary at Demetrias and the alleged funerary sanctuaries of Thessaly}

A re-appraisal

Maria Stamatopoulou

\section{(2) OpenEdition \\ Journals}

Electronic version

URL: http://journals.openedition.org/kernos/2281

DOI: 10.4000/kernos.2281

ISSN: 2034-7871

Publisher

Centre international d'étude de la religion grecque antique

\section{Printed version}

Date of publication: 1 November 2014

Number of pages: $207-255$

ISBN: 978-2-87562-055-2

ISSN: 0776-3824

Electronic reference

Maria Stamatopoulou, « The Pasikrata Sanctuary at Demetrias and the alleged funerary sanctuaries of Thessaly », Kernos [Online], 27 | 2014, Online since 01 October 2016, connection on 20 April 2019.

URL : http://journals.openedition.org/kernos/2281 ; DOI : 10.4000/kernos.2281

This text was automatically generated on 20 April 2019.

Kernos 


\title{
The Pasikrata Sanctuary at Demetrias and the alleged funerary sanctuaries of Thessaly
}

A re-appraisal*

\author{
Maria Stamatopoulou
}

\section{Introduction - History of the investigations at the site}

1 During his investigations in the southern cemetery of Demetrias (Fig. 1), A.S. Arvanitopoulos excavated between 1912-1915 a number of deep pits that were found scattered among graves of various periods, reportedly near the remains of a medieval building (Fig. 2). According to him, the pits were located very near the $5^{\text {th }}$ Stelai-tower and a gate of the fortification wall, by the road to Alykes (Fig. 3). ${ }^{1}$ Most of the pits were small in size and contained clay figurines. A larger pit discovered at considerable depth contained stone inscribed altars, marble statuettes, stone inscribed stelai and a life-size marble head, ${ }^{2}$ while another pit, found very close to the modern ground surface, contained clay figurines, clay altars with elaborate decoration, pots, lamps, small votives, heads belonging to marble statuettes and parts of a large scale clay bust or statue. ${ }^{3}$

2 Based on the numerous objects of votive character in the pits, Arvanitopoulos ascribed the finds to a sanctuary of Pasikrata, named in the inscriptions, whom he identified with Aphrodite because of a few statuettes depicting the goddess, and Artemis En(n)odia and proposed that it was in use from the $3^{\text {rd }}$ century $\mathrm{BC}$ to the late $2^{\text {nd }}-3^{\text {rd }}$ century $A D .^{4}$ N. Papachatzis was the first to discuss the sanctuary in depth, in an influential article published in the journal Thessalika of 1958, which established Pasikrata as a funerary deity. He identified Pasikrata with "Aphrodite of the Dead" because he considered the location of the sanctuary, in the vicinity of graves, as indicative of the nature of the venerated deity. His interpretation was widely accepted and led to the characterization of numerous periurban sanctuaries in the region and elsewhere as funerary. 
Since 2002 I have been entrusted with the publication of Arvanitopoulos' excavations in the cemeteries of Demetrias, a project that was seriously hampered by the lack of documentation in the archaeological museums of Volos and Athens and the re-display works in both museums. What will be discussed in this article stems from my work on the site, the study of the relevant archival material and the examination of a large number of the finds. ${ }^{5}$ I hope to show that, contrary to what is usually proposed about the Pasikrata sanctuary, cult at the site was not funerary in nature but rather it aimed at the well-being and the prophylaxis of young women and children.

4 It is very difficult to reconstruct the situation described in the excavation reports of Arvanitopoulos. As noted by the excavator himself, this area had been in continuous use from the $4^{\text {th }}$ century BC to late antiquity, and there was therefore much disturbance at the site. ${ }^{6}$

The excavation was not completed by Arvanitopoulos and no overall plan of the investigated area was ever published. In addition, the excavation daybook of the 1912 season was lost near modern Amyntaio during the Balkan Wars when Arvanitopoulos was drafted. ${ }^{7}$ Finally, the exact site of the sanctuary cannot be identified today because of the alteration of the terrain in the course of the $20^{\text {th }}$ century. ${ }^{8}$ Be that as it may, the photographs illustrating the excavation show that the excavated area lay very near the fortifications and the $5^{\text {th }}$ Stelai-tower, to its south (Fig. 2-4). ${ }^{9}$ The study of the extant excavation daybooks has revealed that Arvanitopoulos investigated only part of the area near the $5^{\text {th }}$ Stelai-tower, as he soon concentrated his efforts further west and south. It seems that after 1912 he did not find more votive deposits. ${ }^{10}$

\section{The Pasikrata Sanctuary at Demetrias}

\section{Location of the sanctuary (Fig. 4)}

6 The pits were indeed situated near graves; however, owing to the disturbance of the area by later use - funerary and other - the exact relationship of the pits to the graves of the Hellenistic and Roman periods is not clear. Moreover, it is likely that a few of the figurines illustrated in the various publications were not found in the deposits themselves but were stray finds, scattered throughout the nearby area. ${ }^{11}$

7 The number, character and date of the objects found in the pits suggest that they belonged to a sanctuary and that their deposition was possibly the result of cleaning operations of the site. No trace of a cult building related to these pits was found in the excavations. This was considered problematic by Arvanitopoulos, who originally suggested that the sanctuary was perhaps located elsewhere and that the offerings were transferred to the site in later times. ${ }^{12}$ Papachatzis considered this unlikely because the finds span a period of at least five centuries and such a removal of an entire sanctuary deposit would, according to him, be a rare occurrence..$^{13}$ As with Demetrias, there are often cases of large deposits found outside the fortifications of settlements, near the cemeteries, containing objects that were most likely collected as a result of cleaning operations of shrines ${ }^{14}$ or of purification of burial grounds, as for example at the Mosè necropolis, east of Acragas, ${ }^{15}$ or the very large deposit at Amphissa in Phocis. ${ }^{16}$ At the latter, apit measuring $2.65 \times 1.75 \mathrm{~m}$ was investigated near the ancient cemetery and contained 1,003 coins and nearly 900 figurines of various types, mainly female figures, women with birds, kourotrophic images, animal figurines, grotesques, kernoi, miniature 
vessels, small plaques. The character of the finds suggests that they belong to a sanctuary deposit. Yet, contrary to the Amphissa deposit where epigraphic evidence is lacking, at Demetrias the presence of inscribed votive stelai and incense burners and the base mentioning a priestess of Pasikrata (Fig. 19) make it certain that we are dealing with artefacts coming from a sanctuary. The absence of architectural remains need not be problematic, ${ }^{17}$ especially given the disturbance of the area. At Syracuse in the sanctuary of (most likely) Demeter and Kore at Piazza della Vittoria in the Achradina district, architectural remains of the cult/temple building were very limited and identifiable only by the negative of the foundation trenches of the walls. ${ }^{18}$

8 Regarding the Pasikrata sanctuary, it is likely that either Arvanitopoulos did not identify the building among the various walls which he excavated (and ascribed to funerary buildings) or that if there was originally a cult-building it was made of modest materials which did not fare well with time and were dismissed by him as 'later'/ 'crude'. Of course we should not exclude the possibility that, during the enlargement of the fortifications and the extension of the towers at the southern part of the city walls of Demetrias, there were changes in the area and that the sanctuary's contents were moved from their original location. This might be supported by the discovery, at the lower levels of the $5^{\text {th }}$ Stelai-Tower, of figurines identical to those found in the pits. ${ }^{19}$ In any case, the fact remains that the sanctuary was located very near one of the city gates of Demetrias, most likely outside the fortifications, in the southern sector of the city, overlooking the harbour/bay (at modern Alykes).

\section{The finds}

9 The votives included a very large number of clay figurines, datable from the $3^{\text {rd }}$ century $\mathrm{BC}$ to the $2^{\text {nd }}$ century $\mathrm{AD}$, but predominantly of Hellenistic date..$^{20}$ The recent re-discovery of the figurines in the National Archaeological Museum in Athens has demonstrated their typological variety and has shown that the most popular types were: ${ }^{21}$ dressed standing or, less often, seated women of the 'Tanagra' type, figurines of young females and girls, and boys in Macedonian dress, with kausia, short belted chiton, chlamys and boots (Fig. 56). ${ }^{22}$

10 A number of statuettes and relief clay plaques depict Aphrodite, singly or in the company of Eros. Notable among the figurines are the statuettes of a kourotrophos, a bull attacked by a dog, a hydriaphoros, a bovine protome, and the Roman period emblema(Fig. 7). ${ }^{23}$

11 Part of a large-scale clay bust or statue, representing a female figure dressed in a highgirded peplos (Fig. 8), ${ }^{24}$ and other fragments suggest that there may have originally been large-scale clay sculpture. ${ }^{25}$ The discovery of clay 'figurine-patrices', if not coincidental, should point to the existence of pottery workshops in the nearby area (Fig. 7, top row the $3^{\text {rd }}$ and $4^{\text {th }}$ from the left; Fig. 9-10). ${ }^{26}$ This would be in agreement with other Thessalian sites, for example Metropolis and Pherai, where pottery workshops were located very near the fortification walls. ${ }^{27}$

According to Arvanitopoulos, pottery finds were plentiful, but unfortunately only a few can be identified with certainty, a fact that hinders its interpretation in this context: ${ }^{28}$ these are of Hellenistic and Roman date and include, cups, jugs, small bowls, an incense burner andnumerous lamps (Fig. 11-12). ${ }^{29}$ Notable among the pottery is a clay West-slope deep phiale, bearing on the relief medallion an erotic scene in the presence of Eros (Fig. 13). .30 

are: the stone base for the dedication of the priestess Theano, daughter of Theotimos, to mark the completion of her service as a priestess, in letters of the $3^{\text {rd }} \mathrm{C} \mathrm{BC} \mathrm{(Fig.} \mathrm{19);}{ }^{37}$ two naiskos stelai of the $3^{\text {rd }}$ century $\mathrm{BC}$ naming women, the dedication of Boubalis to Pasikrata (Fig. 20), ${ }^{38}$ and that of Melita, daughter of Gerostratos (Fig. 21); ${ }^{39}$ two small marble inscribed altars (incense burners?) dedicated by men: the small cylindrical altar bearing the dedication by Menekrates and Demetrios to Artemis Enodia, dated to the early $2^{\text {nd }}$ century BC (Fig. 22), ${ }^{40}$ and the cubic altar with the dedication by Protas in letters of the $2^{\text {nd }}$ century AD (Fig. 23);41 and a shaft stele dedicated by Zopyros and Hippolyte for the wellbeing of their daughters inscribed in letters of the late $3^{\text {rd }}-$ early $2^{\text {nd }}$ century BC (Fig. 24). ${ }^{42}$ The dedicatory formulas on the votives addressed to Pasikrata, euxamene on the stele offered by Melita, euchen on the small altar naming Protas, are indicative of the assisting nature of the deity. An unpublished fragmentary stele in the Volos Museum bears a dedication by -ima the daughter of Antiochos to [Pas]ikrata epekoos as gift, in letters that suggest a date in the $1^{\text {st }}-2^{\text {nd }}$ centuries $\mathrm{AD}$; it preserves part of its relief decoration, possibly an ear. Heinz has attributed it to the Pasikrata sanctuary; if it were really from the site it would offer significant clues to the character of the deity. ${ }^{43}$

It is evident from the type and number of votives that this was an organised sanctuary, with a priesthood, that received dedications by both men and women, and was in use from the $3^{\text {rd }}$ century $\mathrm{BC}$ to the $2^{\text {nd }}$ century AD. The material evidence is too meagre to enable a reconstruction of the ritual, however it had involved the burning of offerings on the small altars/incense burners, ${ }^{44}$ and possibly nocturnal rituals. ${ }^{45}$ The votive offerings reveal a strong association with women and children, both boys and girls. The emphasis on the well-being and prophylaxis of children/young persons is further hinted at by the

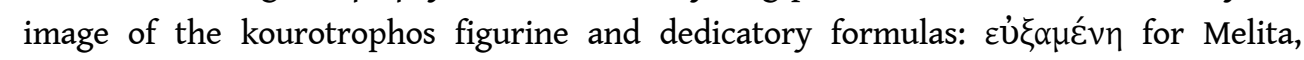
daughter of Gerostratos, ن் $\dot{\varepsilon} \rho \tau \tilde{\omega} v$ $\theta u \gamma \alpha \tau \varepsilon \rho \omega \nu$ in the dedication of Zopyros and Hippolyte, and عن̉xńv for Protas. ${ }^{46}$

\section{The venerated deities}

17 The deity/ies worshipped in the sanctuary are Pasikrata and Artemis En(n)odia. Pasikrata is evidently an epiclesis, similar to that of Pankrates in Athens. ${ }^{47}$ Arvanitopoulos linked Pasikrata with Aphrodite because of the presence of the Aphrodite figurines and the marble female head, which he identified as belonging the cult statue of the goddess. ${ }^{48}$ Papachatzis first, and then most scholars, have called her 'Aphrodite of the dead', because of the presence of Aphrodite figurines among the finds, the location of the sanctuary within a cemetery, and the strong association of the cult with women. ${ }^{49}$ Papachatzis had stressed the emphasis on the well being of children and fertility but he saw no contradiction between a funerary and a kourotrophic cult at the same site..$^{50}$ 
18 A cult of Aphrodite in a cemetery at first appears out of place. Literary sources attest to her cult in relation to the dead, for example Plutarch refers to Aphrodite as epitymbia at Delphi, ${ }^{51}$ where she received libations aimed to recall the dead. However, we should bear in mind the Roman date of these testimonia, which thus may not reflect realities of the Hellenistic period.

19 The archaeological evidence suggests that in various regions during the Hellenistic period, especially Macedonia, there was a pronounced interest in Aphrodite and her circle in funerary contexts. This is implied by the large number of figurines of Aphrodite, Erotes, naked women, females and protomai deposited in, mainly, female graves, aiming to ensure her protection. ${ }^{52}$ Some have seen these as evidence for the assimilation of the cult of Aphrodite and Persephone. Demetrias was a Macedonian foundation, therefore the existence of similar cults/phenomena is likely. ${ }^{53}$ At the same time we should bear in mind that the placing of female statuettes, female busts, jewellery and Erotes in female graves could be related to the age of the deceased, who in some cases have been shown to be young mothers or girls of marriageable age. ${ }^{54}$ It has become increasingly common to identify female protomai or busts found in $4^{\text {th }}$ century and Hellenistic graves as 'Pasikrata/Aphrodite of the Dead', often without adequate justification for the characterization. ${ }^{55}$ In votive contexts recent scholarship has questioned the association of protomai with a specific deity/ies, let alone with 'chthonic'-funerary ones, ${ }^{56}$ but in funerary contexts the issue is still under debate and systematic studies are lacking. ${ }^{57}$ Moreover, it is well known that the cult of deities such Artemis, Aphrodite, Persephone can be multifarious and should be examined in their specific, regional, context/audience, as is evident at Locri Epizephyrii, where Persephone was venerated as protector of marriage and young women. ${ }^{58}$

Pasikrata/eia is attested outside Demetrias in Epirus, northern Macedonia and Sicily. ${ }^{59}$ In the sanctuary of Demeter Malophoros at Selinous, outside the city gates, Pasikrateia was worshipped together with Malophoros and Zeus Meilichios; she has been plausibly identified with Persephone or Artemis. ${ }^{60}$ In Epirus Pasikrata was used as an epiclesis for Artemis on two votive monuments dedicated by men, found at Ambrakia ${ }^{61}$ and Panagia Prevezas. ${ }^{62}$ In ancient Herakleia Lynkestis (Sudovol), Pasikrata was related to the manumission of slaves in a sanctuary of the $3^{\text {rd }}$ c. AD. ${ }^{63}$

21 The preliminary study of the finds from the Pasikrata sanctuary reveals that its close geographical proximity with the cemetery does not seem to have involved distinct votive offerings, different from the ones we should expect in urban sanctuaries. ${ }^{64}$ The similarity to the offerings of the favissa on Hill 35, ${ }^{65}$ and the so-called 'Thesmophorion' at the eastern edge of the city, near the fortification walls, is significant. ${ }^{66}$ The votives from the Pasikrata sanctuary suggest cult performed by both women and men/youths, and dedications of terracotta images of children (boys and girls), young females, ${ }^{67}$ or dedications for the well-being and prophylaxis of children.

Although attested, Aphrodite was not a major kourotrophic deity. ${ }^{68}$ The other deity mentioned in the inscriptions and depicted in the marble statuettes is Artemis En(n)odia. ${ }^{69}$ As is well known En(n)odia is an indigenous deity, whose cult was widespread in Thessaly and is attested epigraphically in the region from the $5^{\text {th }}$ century. ${ }^{70}$ She is represented on reliefs and Pheraean coins standing or on horseback, with one or two torches, accompanied by her favourite animal attributes, a dog or horse. A goddess that protects pathways and crossroads, En(n)odia is also, especially in the interpretations by Kraus and Chrysostomou, a 'chthonian' deity, ${ }^{71}$ or goddess of the underworld, worshipped 
in cemeteries, related to ghosts and witchcraft (Polyaenus, Strategemata, VIII, 43).72 M. Mili and D. Graninger have justly challenged this dominant 'chthonic'/funerary feature of En(n)odia. ${ }^{73}$ Outside Thessaly, she was assimilated with Artemis and in particular with Hekate, with whom she also shared the connection with to pathways and crossroads and her kourotrophic functions.

\section{The so-called 'funerary' sanctuaries}

\section{Periurban sanctuaries of En(n)odia and other deities in Thessaly}

$\mathrm{BC}$ could be related to its proximity to a water source and a major road, the one leading to Larisa. ${ }^{80}$ Mazarakis Ainian has shown that during the Late Geometric period urban sanctuaries were often founded in areas that had previously been burial grounds. ${ }^{81}$ The memory that there were graves at the site might have worked at another level: setting the site aside for ritual use as in the case of the shrines at the SW corner of the Athenian agora. ${ }^{82}$

The dedication of the sanctuary to En(n)odia and Zeus Thaulios during the Classical and Hellenistic periods is undisputed. As proposed by Mili in her doctoral thesis, ${ }^{83}$ a funerary aspect of her cult is highly unlikely for various reasons. Firstly, because of the scale and size of the sanctuary. What is usually discovered in cemeteries are modest constructions, usually of oikos or megaron plan. ${ }^{84}$ By contrast the large stone peripteral Doric temple is carefully built and among the most monumental Thessalian temples. Secondly, fourteen decrees of the city of Pherai were found in the temple and favissae area. Among them were proxeny decrees and an inventory list of votives, recording dedications by civic magistrates, a feature that suggests that this was a major civic sanctuary ${ }^{85}$ It is highly 
unlikely that the decrees of a city would have been set in a cemetery or that magistrates would be making dedications in a funerary shrine. ${ }^{86}$ Bearing in mind the considerable investment in the sanctuary and the type of dedications it is therefore more likely that the location of the temple is in agreement with a civic role of for En(n)odia. Epigraphic evidence from Thessaly provides us with ample evidence for civic functions of En(n)odia: ${ }^{87}$ she is called Fastika in a $5^{\text {th }}$-century inscription from Larisa, ${ }^{88}$ Patroa in Pagasai and Larisa, Polias in other cities. ${ }^{89}$

Although the course of the fortification walls in this part of Pherai is not yet known, it is evident that the sanctuary was very near the city, and next to a major road. The location of the sanctuary is in agreement with En(n)odia's role as an intermediary, a protector of roads and crossroads. It is paralleled in Thessaly at numerous sites, for example at Phthiotic Thebes, where votive stelai were found outside but near the southern part of the city walls, ${ }^{90}$ and Larisa, where in an inscription that refers to the area outside the southern fortification wall, there is mention of a stele dedicated to En(n)odia that was set outside the gates among other shrines and cult places. ${ }^{91}$

The other periurban sanctuary of Pherai where En(n)odia was most probably venerated was found at the locality Alepotrypes in the southwest cemetery of the city, near the fortification walls (Fig. 25).92 There, following the destruction of graves by the owner of the land, the foundations of a building, rectangular in plan, were excavated, almost at surface level, ${ }^{93}$ among graves of the Early Iron Age and Hellenistic period. ${ }^{94}$ Inside the building, near its northwest corner, ${ }^{95}$ a large shallow pit was found that contained numerous objects of votive character, such as the lower part of a marble two-sided relief and its base, clay figurines of seated and standing female figures, parts of a large clay thymiaterion, a clay coiled snake, two clay heads depicting bearded men and parts of a large-scale clay sculpture. ${ }^{96}$ More fragments of clay figurines and clay female protomai were found in the fill of the building and outside, to its west. As the artefacts suggest, the sanctuary must have been in use in the Classical and Hellenistic periods, from the $5^{\text {th }}$ century BC onwards. ${ }^{97}$

A marble votive stele that had been re-used as a side of a cist grave of late Hellenistic date that had destroyed part of the northwest wall of the building, ${ }^{98}$ bearsa dedicatory inscription which is extremely difficult to read (and has been dated on letter forms to the mid- $4^{\text {th }}$ century). According to Chrysostomou, it names En(n)odia and another god, whose name is mostly lost, which he reconstructs as Zeus Meilichios. ${ }^{99}$ Even if Chrysostomou's reading is incorrect, as the editors of SEG propose, ${ }^{100}$ theidentification of the deity worshipped at the shrine with En(n)odia is probable given the importance of her cult at Pherai and the type of some of the finds, namely, the clay figurine showing a standing female figure, dressed in a peplos and holding in both hands two long rods, which could be torches (Fig. 27). ${ }^{101}$ The typological similarity to representations of En(n)odia on Hellenistic votive stelai, particularly the relief from Exochi, is clear. ${ }^{102}$ The discovery of the front part of a clay horse, one of her sacred animals, in the same deposit may also be relevant. ${ }^{103}$

The identification of the male divinity worshipped at the site with Zeus Meilichios rested on the discovery of two almost life-size clay heads of bearded male figures in the same deposit. The best preserved one, dated on stylistic grounds to the second half of the $5^{\text {th }}$ century BC, has its lower part hollow, possibly in order to be secured to a wooden post (Fig. 28). ${ }^{104}$ The austere facial features can suit any of the mature gods: Poseidon, Zeus or Hades. ${ }^{105}$ The discovery of parts of a clay coiled snake next to the head has been seen as a 
'chthonic' element, ${ }^{106}$ and has led to the identification of the figure as Zeus Meilichios, a god often depicted in the form of a snake, whose cult is well-attested in Thessaly during the Classical and Hellenistic periods. ${ }^{107}$ The presence of Zeus in relation to En(n)odia would not be out of place in Thessaly. The two gods were venerated together in the major sanctuary of En(n)odia at Pherai. Moreover, a votive naos was dedicated to En(n)odia and Zeus Meilichios by Makon, a prominent citizen of Larisa, in the $2^{\text {nd }}$ century BC. ${ }^{108}$

31 The cult of Zeus Meilichios in burial grounds is well attested from numerous sites, for example at Palaiopolis on Andros, where in the eastern cemetery of the city a boundary inscription carved on the face of the rock designated the area as a shrine to the god. ${ }^{109} \mathrm{In}$ Rhodes, adjacent to the exterior face of the southern part of the fortification wall were groups of pyres in small pits lined with stones, containing small cups, olpai, animal bones and lamps; one of the pyres, no. 18, preserved on its lid an inscription in the genitive that showed that the area was consecrated to Zeus Meilichios, and in use in the $3^{\text {rd }}$ century BC. ${ }^{110}$ Near Cyrene, at Ain Hofra, niches and votive inscriptions to Zeus Meilichios and the Eumenides were found in an area that was in very close proximity to graves, namely the 'Archaic tomb sanctuary'. ${ }^{111}$ It has been stressed in scholarship that cult to Zeus Meilichios was often performed by kinship and gentilitial groups, aiming to avert the danger of pollution in death, or for purification of murder. ${ }^{112}$ Therefore, the veneration of Zeus Meilichios in such contexts is easily explained and perhaps finds parallels in the cult of Zeus Meilichios or Phonios outside city gates.

To summarize, the shrine at Alepotrypes was in use from the late $5^{\text {th }} /$ early $4^{\text {th }}$ centuries $\mathrm{BC}$ until the Hellenistic period, when it was destroyed by graves built on the walls of the building. The location, size and construction of the building and the type of finds do not preclude that it was funerary in character, however a parallel, contemporary, use of the sanctuary and the burial ground is not proven. Thus, the precise relationship of the building to contemporary graves is uncertain. Despite these limitations and although the inscribed votive stele was not found in situ, the cumulative evidence from the sanctuary implies that the identification of the main female deity worshipped at the site with En (n)odia is reasonable. The location of the sanctuary at Alepotrypes is significant. The proximity to the fortifications, a water source and a road are all features that this shrine shares with the large sanctuary of En(n)odia at the northeast periphery of Pherai. Could the cult of En(n)odia at this site have been related to her role as protector of gates and passes and not to the dead?

33 Two inscriptions, from Skotoussa ${ }^{113}$ and Larisa, offer invaluable information about cult places in the proximity of city walls. The Larisa inscription is an inventory of sacred spaces situated near and outside city walls. ${ }^{114}$ It mentions numerous shrines dedicated to gods, such as Athena Patria, Apollo Pythios, but also cult places and stelai dedicated to En (n)odia, Demeter Ploutia, Zeus Phonios, various heroes, as well as the hipparcheion. It has been proposed that the areas described in the inventory were probably situated on a low hill, very near the southwest cemetery of the city. Although some cults, like that of Zeus Phonios, or En(n)odia Mykaike could perhaps be seen to have underworld connotations, ${ }^{115}$ the same is not tenable for all cult places described in the inscription. ${ }^{116}$

34 I do not want to exclude the possibility of cult of Underworld deities and/or dead ancestors in shrines that were deliberately founded within cemeteries. ${ }^{117} \mathrm{~A}$ possible example in Thessaly could be the 'oikoi' excavated by B. Intzesiloglou at Prodromos near Karditsa. There, during small-scale rescue excavations on the southeastern border of the village, at the locality Bourdenia, a small part of a cemetery was discovered, with burials 
dating to the late $6^{\text {th }}$ and first half of the $5^{\text {th }}$ century. ${ }^{118} \mathrm{Among}$ the graves, about $20 \mathrm{~m}$ west-soutwest, the foundations of four small buildings were found at very shallow depth, near the modern surface, one next to the other, built of fragments of Laconian roof tiles. According to the excavator, one of the foundations is of the megaron type, while the other three are simple 'oikoi', that is, they consist of a simple rectangular room, approximately $4.60 \mathrm{~m}$ by $4.20 \mathrm{~m}$, with the entrance opening to the south and a wall width of about $0.40 \mathrm{~m} .{ }^{119}$ Shallow pits were found among the buildings and contained clay figurines depicting riders, standing or seated female figures wearing a high polos, and fragments of coarsely hand-made kernoi, which have been dated on stylistic grounds to the late $6^{\text {th }}$ and early $5^{\text {th }}$ centuries BC. Based on the votive character of these finds, the excavator interpreted this area as belonging to a sanctuary. The proximity to the burial ground and the contemporary use of the buildings to the graves would be in agreement with an identification as a funerary sanctuary. But as nothing diagnostic was found inside the 'oikoi' and the divinity venerated at the site is not known, we cannot be certain whether the buildings were used for cult of underworld deities.

I also do not wish to deny the existence of ritual performances in relation to tombs. A puzzling structure has been investigated in the northern cemetery of Demetrias, namely a semi-circular theatre-like exedra, cut in the rock and offering a good view to the Gulf of Pagasai (Fig. 1, no. 2; Fig. 29). ${ }^{120}$ The location of the exedra among the graves could imply the performance of rituals in relation to the dead. However, in the absence of any finds from it, neither its date nor the character of the rituals performed can be ascertained. ${ }^{121}$ The wish to ensure divine protection for the dead is expressed in Thessaly by the dedication of the Hellenistic gravestones to Hermes Chthonios, through the depiction of a herm and/or a dedicatory inscription to him in dative or genitive. ${ }^{122}$ A similar wish to ensure divine protection and a better future in the afterlife is revealed by the discovery, in some Thessalian graves of the late $4^{\text {th }}$ and $3^{\text {rd }}$ centuries $B C$, of gold inscribed strips, addressed to Persephone, Dionysos, and Demeter Chthonia. ${ }^{123}$

What I would like to point out is that, similarly to the situation within Thessaly, in most of the cases where sanctuaries or buildings were identified in proximity to cemeteries, and where a 'funerary' aspect has been proposed for the cult/purpose of the building, the evidence was problematic, either because of the limited exploration of the site or because of a chronological gap between the burials and cult activity. ${ }^{124}$

The interpretation of Thessalian periurban sanctuaries as funerary has been heavily influenced by the reconstruction of Thessalian religion proposed by Papachatzis, and recently advocated by Chrysostomou. Papachatzis suggested that in Thessaly, not only Artemis, Aphrodite and Zeus, but also other Olympian deities, such as Athena Itonia and Poseidon, had a strong 'chthonic aspect', especially in early periods, namely the $10^{\text {th }}$ to $6^{\text {th }}$ centuries BC. ${ }^{125}$ This prominence of 'chthonic' cults was attributed to the alleged political and geographical isolation of Thessaly, at least until the Archaic period, an interpretation that was influenced by the evolutionary model of religion and by preconceptions about the primitive character of the Greek ethne. Recent studies, mainly by Morgan and McInerney, on the Greek ethne have shown this to be false. ${ }^{126}$

It is true that $\mathrm{En}(\mathrm{n})$ odia, a deity often worshipped in the Thessalian extramural shrines, appears in, mainly Athenian, literary sources as a goddess related to Demeter and the realm of the dead. ${ }^{127}$ This however need not imply that the shrines found in peri-urban locations in the region, outside the fortifications of the city and often near gates, were 
funerary in character. ${ }^{128}$ The role of the goddess as protector of roads and passes could have been more significant in the choice of location. ${ }^{129}$

\section{Artemis En(n)odia, Artemis and Pasikrata}

40 To return to Demetrias and the cult of Artemis En(n)odia at the site: as mentioned earlier, the small cylindrical altar/incense burner from the sanctuary of Pasikrata mentions Artemis Enodia. Recently García Ramón and Helly have proposed that Artemis En(n)odia resulted from a syncretism between the local En(n)odia and the panhellenic Artemis, to whom they a ascribe kourotrophic role. ${ }^{130}$

41 Artemis is a goddess whose kourotrophic functions are very well documented. ${ }^{131}$ In Thessaly she was worshipped as protector of young children and women at numerous sites. ${ }^{132}$ At Gonnoi, where there was a major intramural sanctuary at the edge of the city near the walls and the gate to Mt Olympos, she bore the epicleseis Eileithyia, Lochia, Eyonymos, Genetaira, and received numerous dedications by women. ${ }^{133}$ She is also known as Lochia at Larisa and Pththiotic Thebes, ${ }^{134}$ Eileithyia (with various spellings) at Larisa, Pythion, ${ }^{135}$ and Throsia at Larisa, Kalochori and Atrax, where her cult might have involved complex rituals that ensured transition of young girls to adulthood. ${ }^{136}$ At Echinos, in the perioikic region of Malis, the well-known votive relief showing the presentation of a baby girl to Artemis and the dedication of clothing to the goddess is a clear indication of the cult of Artemis in the city as protection of childbirth and young children.$^{137} \mathrm{En}(\mathrm{n})$ odia too had probably a kourotrophic role, as was recently advocated by García Ramón and Helly, on the basis of the attested koroutarra on a small stele in the Benaki Museum in Athens, ${ }^{138}$ and strogika patroa (the affectionate) in Larisa. ${ }^{139}$

Given the use of Pasikrata as an epithet of Artemis in Epirus and Macedonia it is likely that the epiclesis Pasikrata at Demetrias could have been linked with Artemis, perhaps in her role as protective goddess of young women and children. ${ }^{140}$ This would fit well both with the dedicatory inscriptions and the location of the sanctuary on the border zone between the settlement and the cemeteries, overlooking the sea, as well as with the plethora of figurines of young women and children among the finds. ${ }^{141}$ Unfortunately the absence of specific formulas in the dedicatory inscriptions or of diagnostic finds, except for the single kourotrophic figurine, among the terracottas that have been studied so far, does not allow us to determine whether the deity was concerned with specific stages of children's lives, and/or whether maturation rituals were practised at the site.

A similar identification has recently been proposed for the formerly-called 'Sanctuary of Aphrodite' at Epidamnos/Dyrrachion. ${ }^{142}$ There, in 1970-71 large votive deposits were found in the cemetery area, belonging to a sanctuary that was possibly located outside the city walls. Finds included black glaze pottery, mostly kotylai, red-figure Apulian vessels, metal objects, 600 small bronze coins. The majority of the finds were terracottas: clay protomai and busts ( $80 \%$ of the terracottas) and female statuettes. The latter included standing draped women, naked women as well as figurines of Artemis, a group of Aphrodite and Eros. ${ }^{143}$ The hypothesis of Muller and Tartari that the sanctuary must have been dedicated to Artemis, as protector of fertility and marriage, was confirmed by the discovery of a graffito mentioning Artemis and Hekate. ${ }^{144}$ Similar to the Demetrias deposits, at Epidamnos/Dyrrachion there is evidence that there was a terracotta workshop in close proximity to the area of the sanctuary. ${ }^{145}$ 

that the cult of Artemis En(n)odia could have also been related to a need to protect the entrance of the city. ${ }^{155}$ L. Kostake, in her discussion of the roadside shrines of Athens, proposed that the concentration of shrines near fortifications and city gates reflects the need to protect these vulnerable areas from enemies and/or sources of miasma. As she pointed out, cult at these Athenian shrines was often to propylaioi divinities or deities related to kourotrophy and/or the protection of children. ${ }^{156}$ Outside Athens, kourotrophic elements have been identified in the cult of many divinities venerated in peri-urban shrines, for example in the cult of Eileithyia at Argos and Corinth, mentioned by Pausanias, at the shrine by the fortifications at Abdera, ${ }^{157}$ or the sanctuary of Demeter at Dion. ${ }^{158}$ With regards to the immediate vicinity of Demetrias we should not forget that in the late Archaic-Classical peri-urban sanctuary of Apollo at Soros (possibly ancient Pagasai), the numerous sculptural dedications of statues of children reveal the important kourotrophic elements in Apollo's cult. ${ }^{159}$

\section{Conclusions} shrines, similar to the Pasikrata one, existed near or within Thessalian cemeteries during the Classical and Hellenistic periods. The location of some (e.g. the Pasikrata one) near the city gates and the frequent presence of $\mathrm{En}(\mathrm{n})$ odia among the venerated deities might imply that cult could have been dedicated to gods protecting the city gates or roads, or to deities with kourotrophic functions.

48

The inventory list in the Larisaean inscription has shown that the space outside the city walls contained various installations: cult places, a hipparcheion, pottery workshops, 
hence the motives behind the selection of the location of a sanctuary were varied and are still not fully understood. The archaeological evidence from Demetrias and the other Thessalian shrines at "liminal" points is much more nuanced that the 'funerary' interpretation would lead us to suppose and invites us to look much more carefully at the peculiarities of each individual case. A systematic study of the peri-urban sanctuaries in Thessaly could provide interesting results and illuminate their role as intermediaries, protecting important passages in the life of members of Thessalian communities.

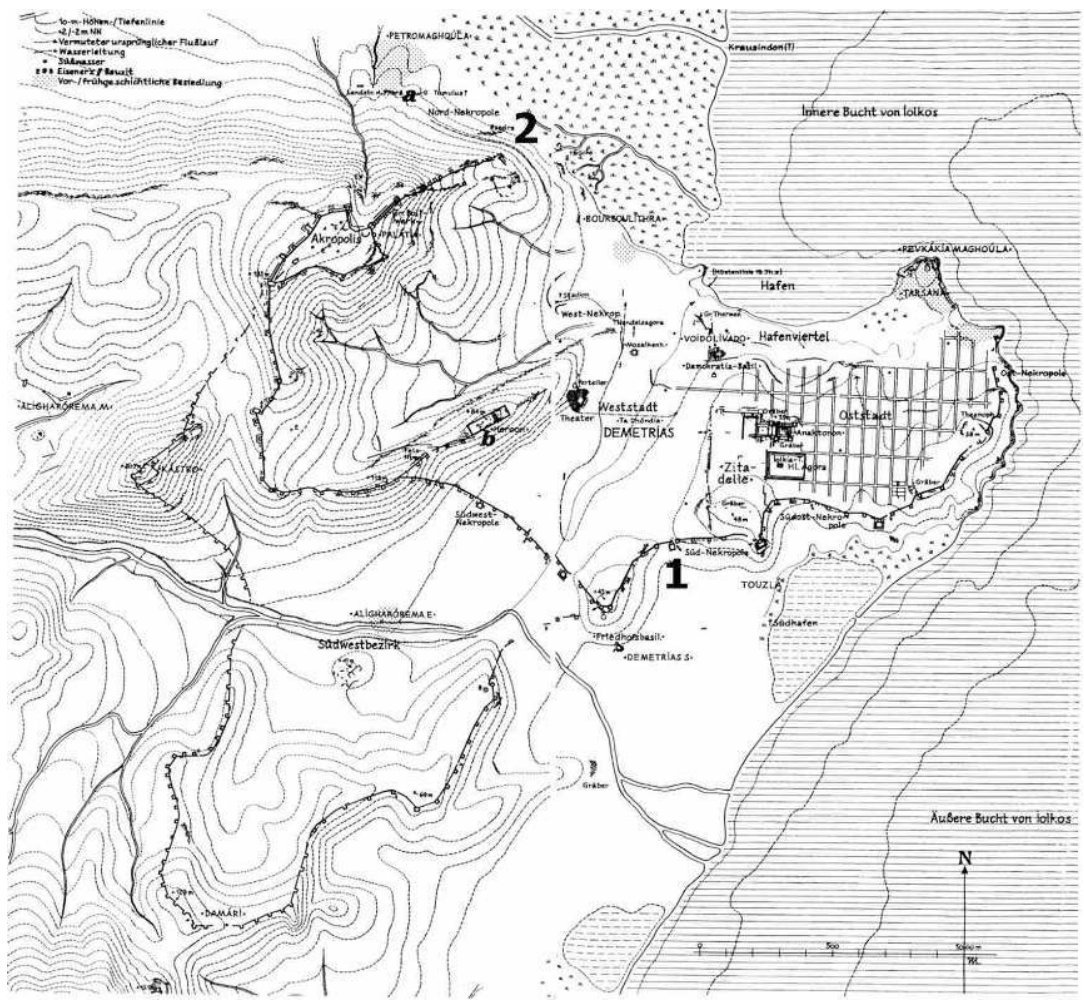

\section{Figure 1}

Plan of Demetrias (source: Marzolff, Demetrias V)

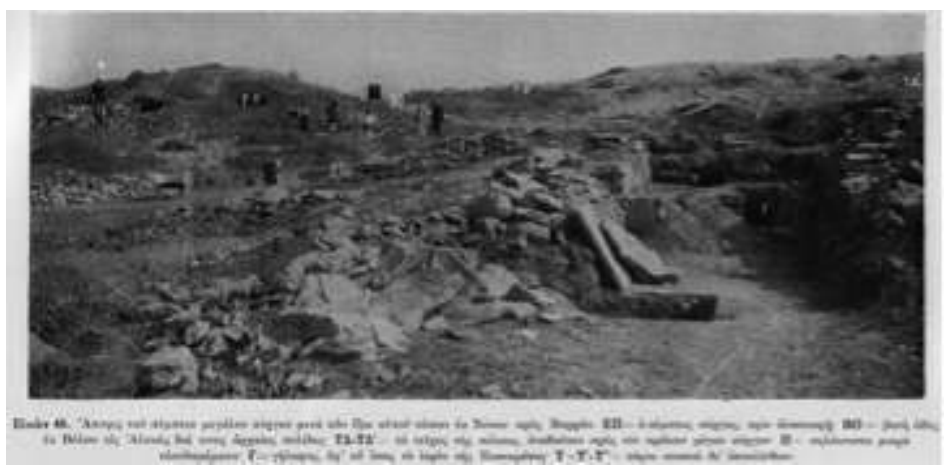

Figure 2

View of the $5^{\text {th }}$ Stelai Tower and its vicinity from S to N (source: GrStelai, p. 43, fig. 46) 


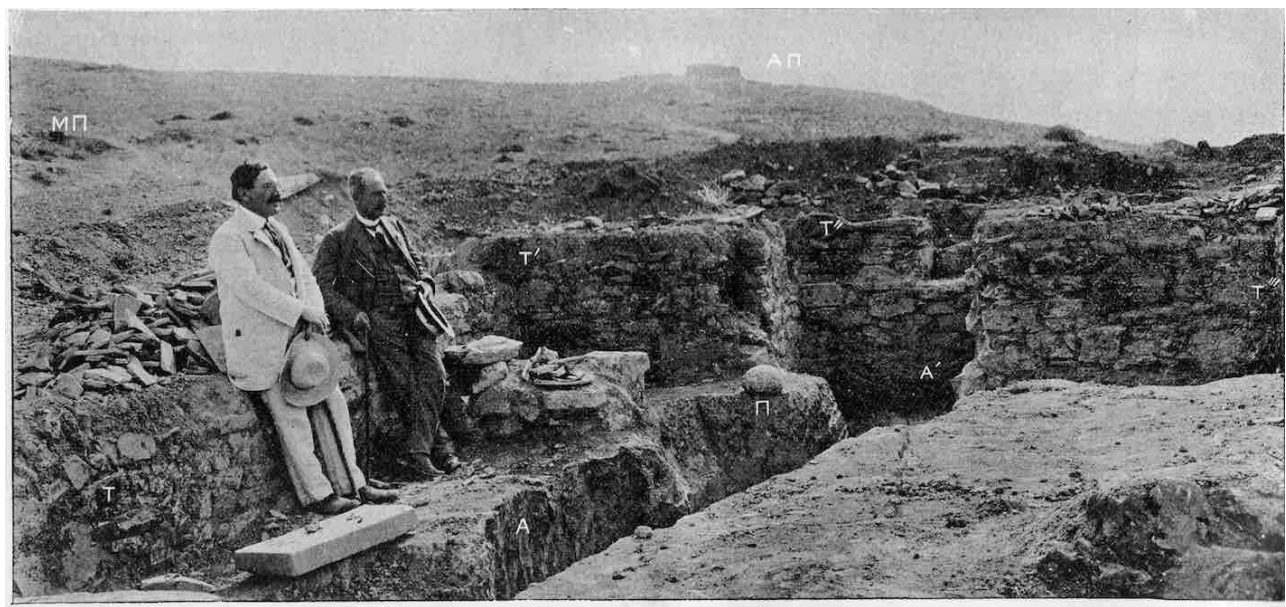

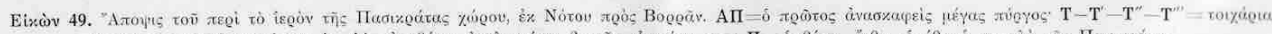

Figure 3

View of the area of the 'Pasikrata' sanctuary, from S to N (source: GrStelai, p. 44, fig. 49).

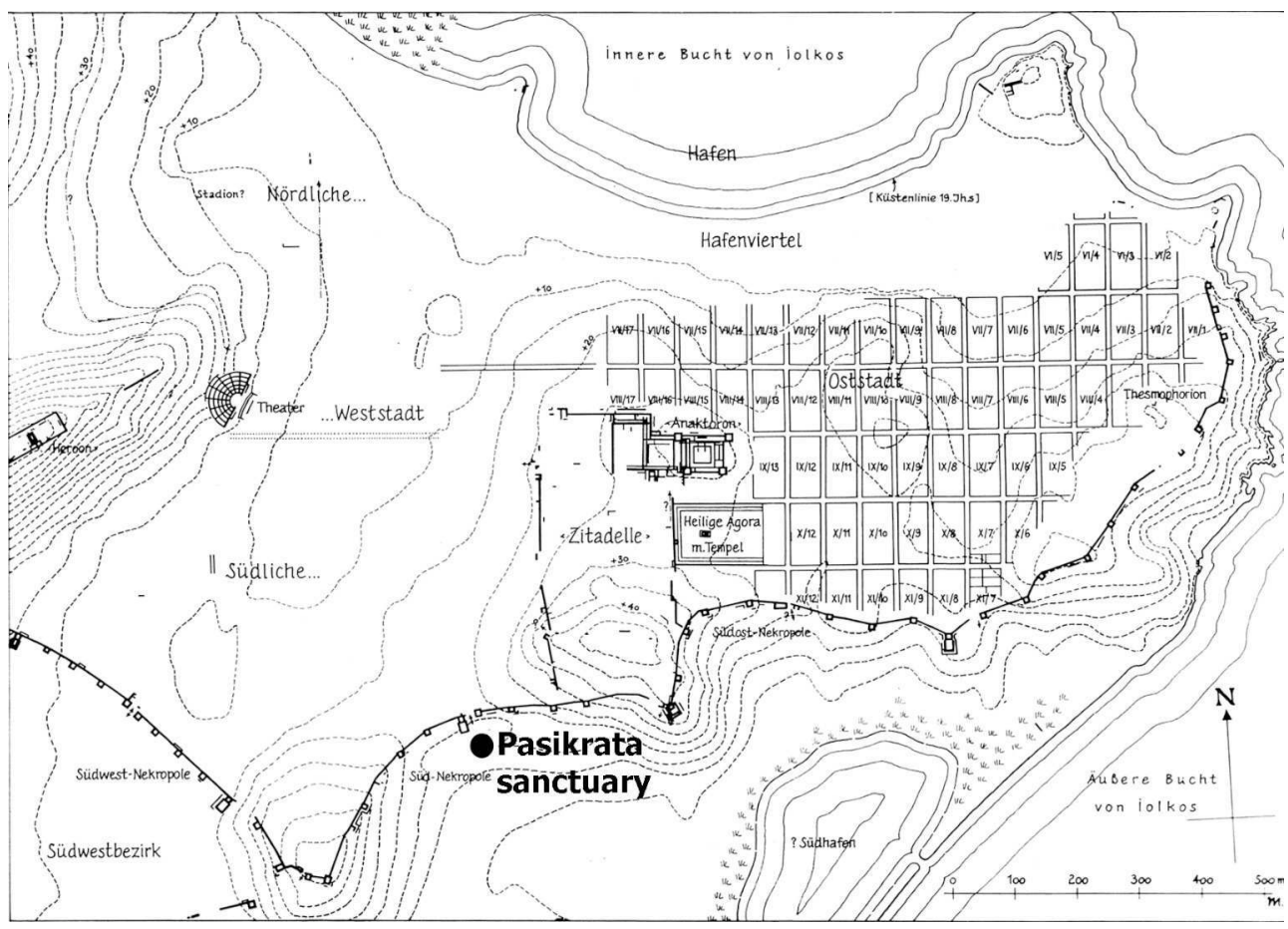

Figure 4

Plan of the eastern sector of Demetrias (source: P. Marzolff) 


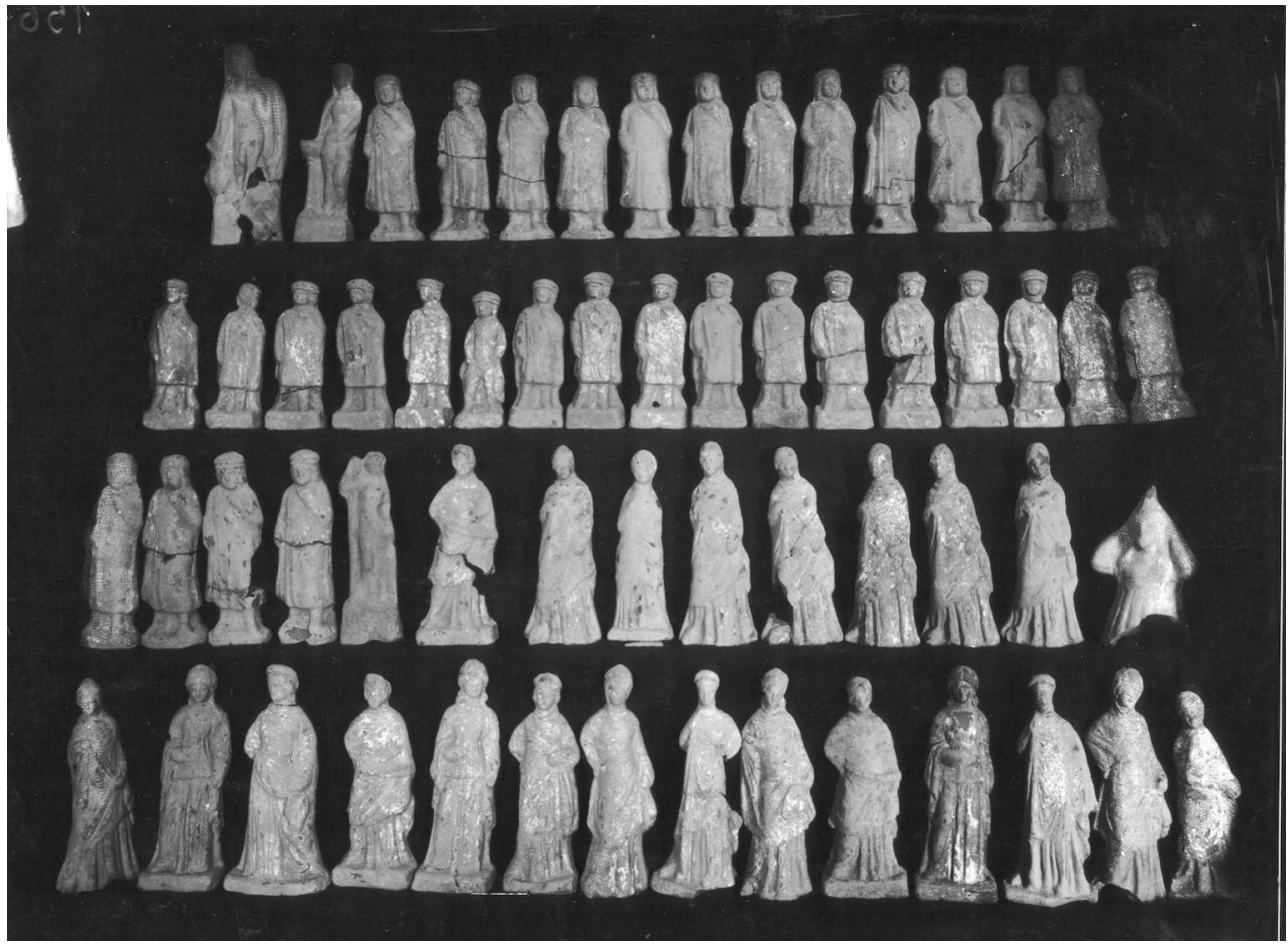

Figure 5

Selection of figurines from the Pasikrata sanctuary, 1912 photo (source: AASA)

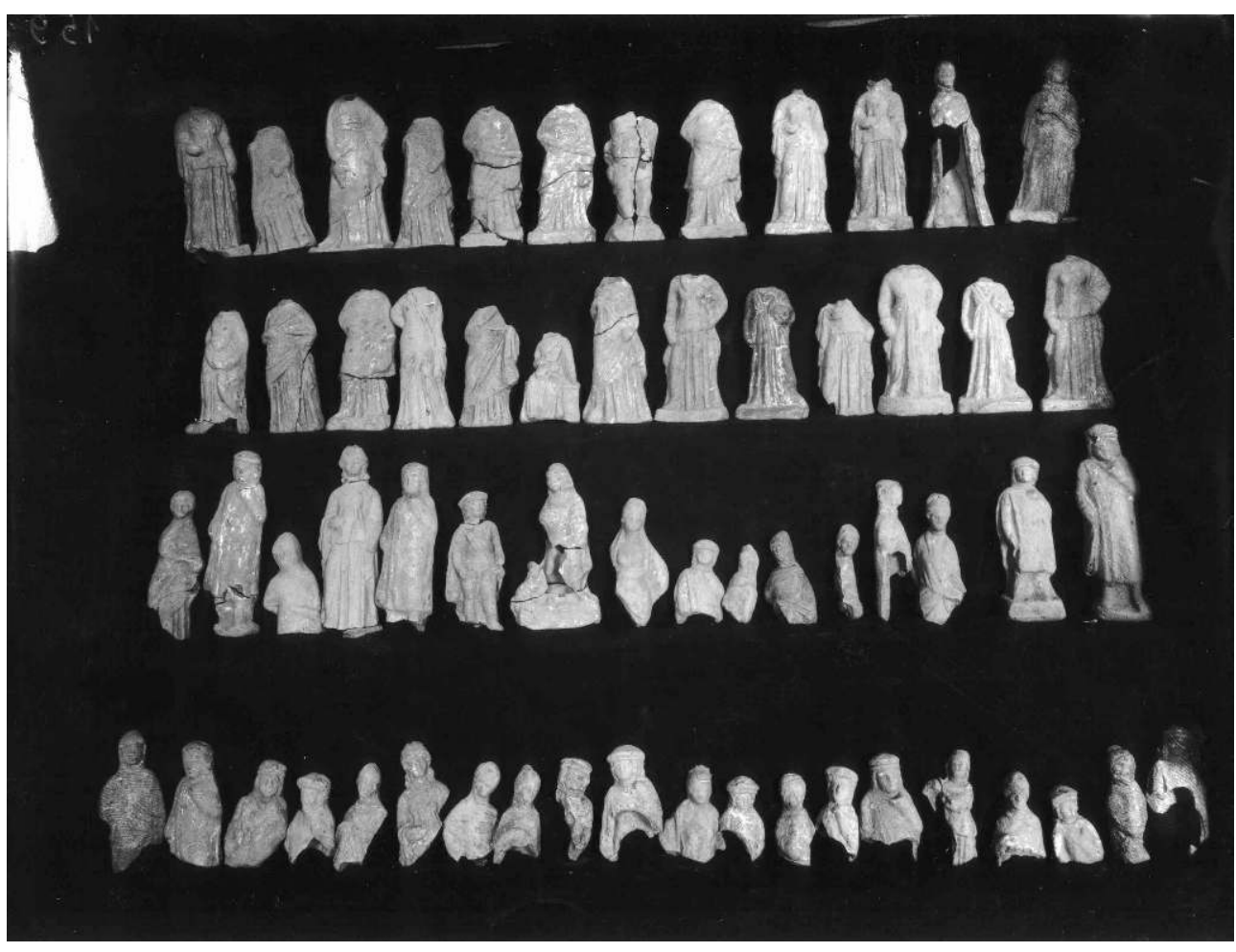

Figure 6

Selection of figurines from the Pasikrata sanctuary, 1912 photo (source: AASA) 


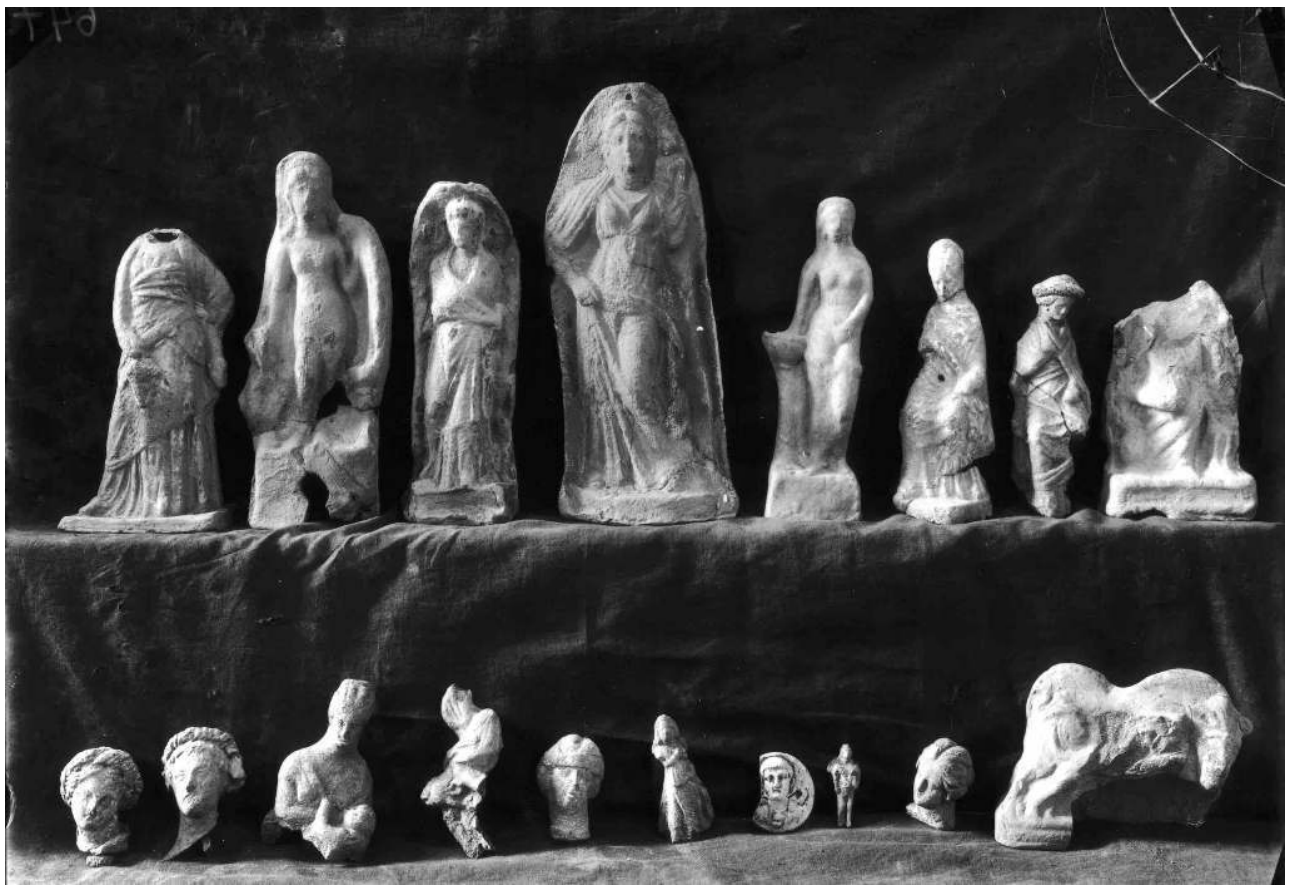

Figure 7

Selection of figurines from the Pasikrata sanctuary, 1912 photo (source: AASA)

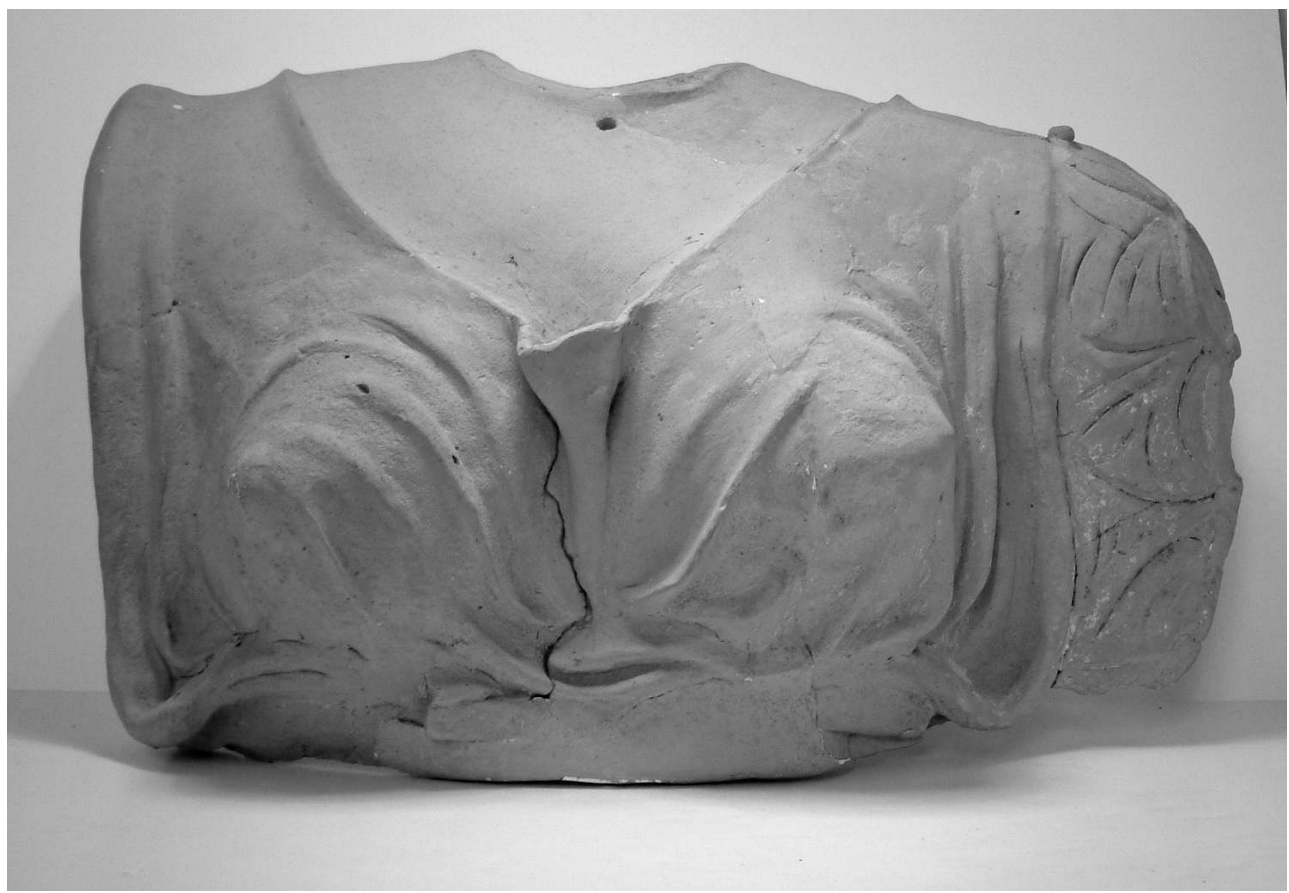

Figure 8

Clay bust/statue from the Pasikrata sanctuary, Volos Museum M2001 (photo: author) 


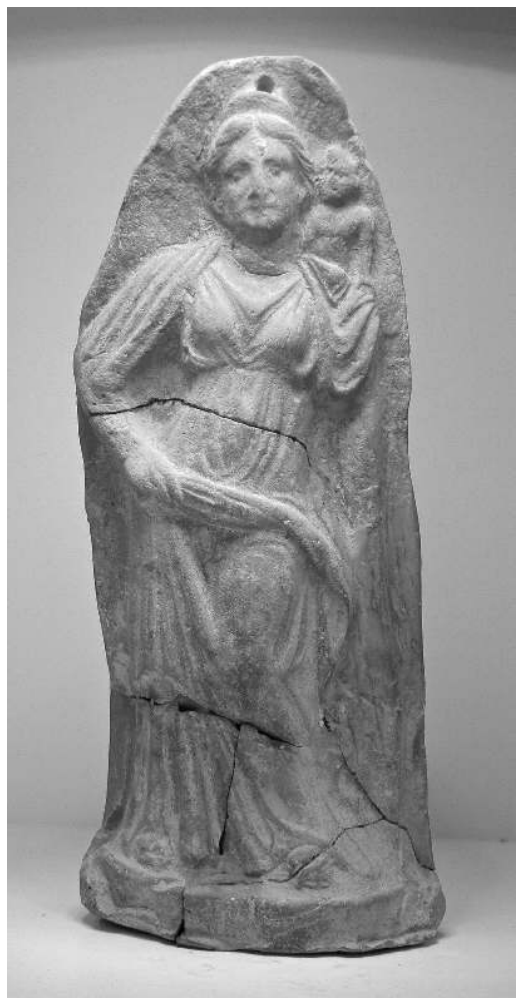

Figure 9

View of the clay figurine-patrice Volos Museum M2002 (photo: author)

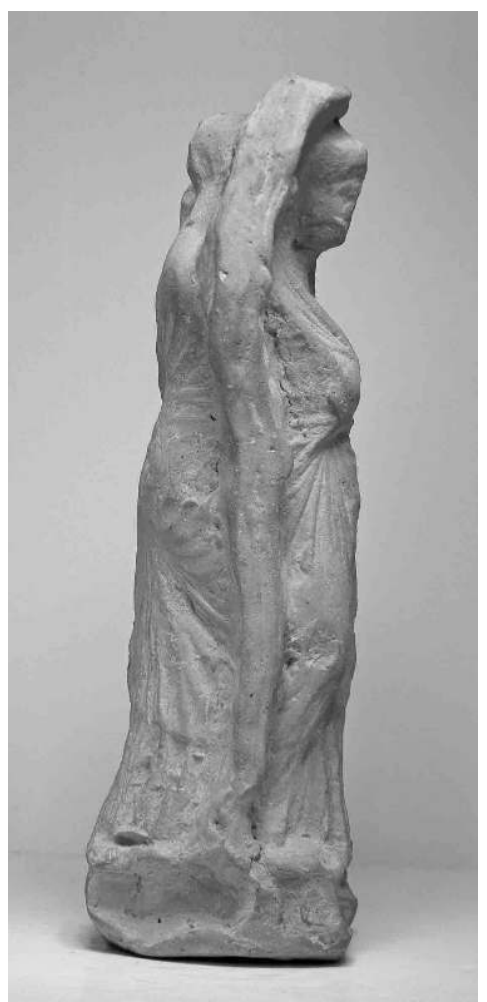

Figure 10

View of the clay figurine-patrice Volos Museum M2004 (photo: author) 


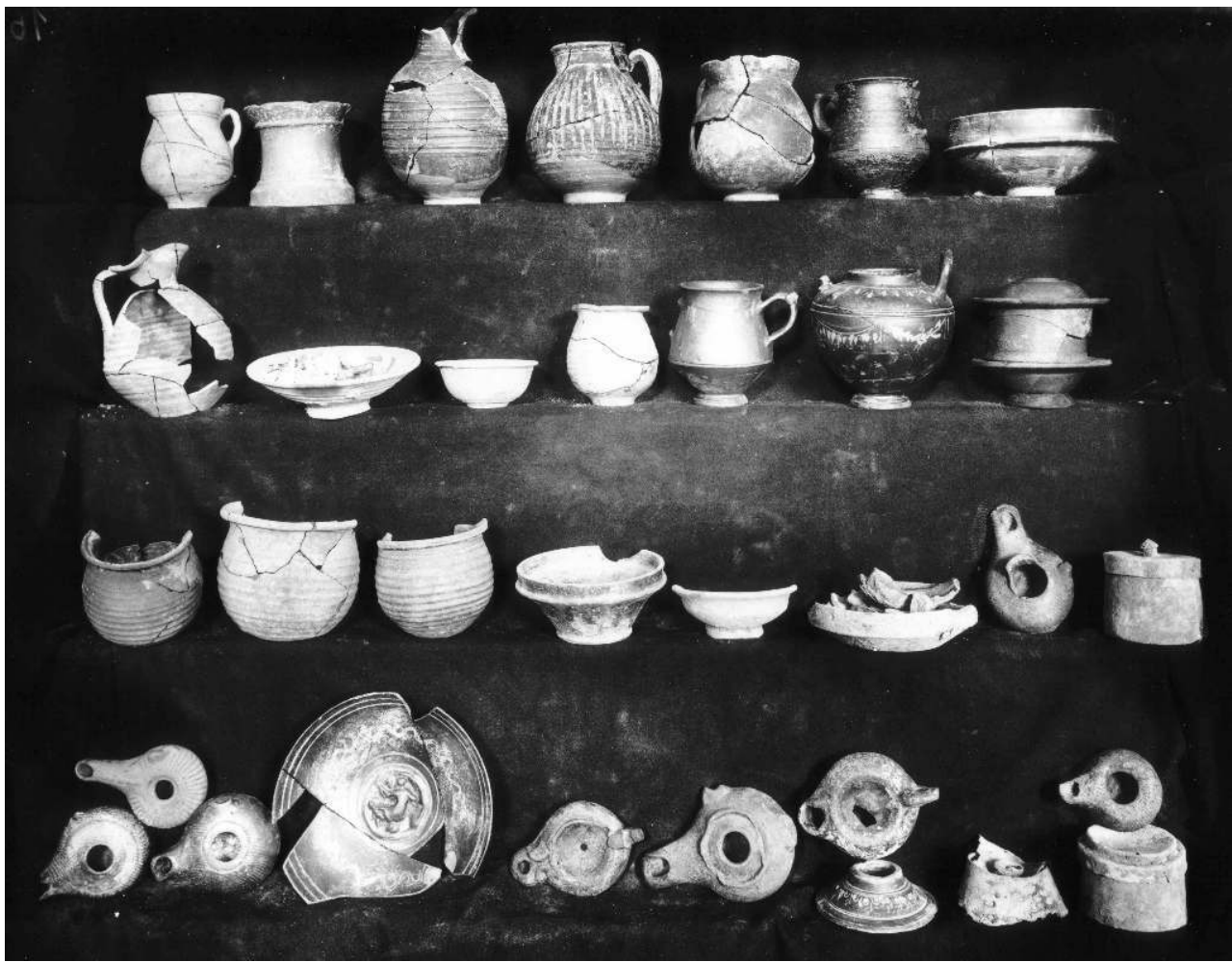

Figure 11

Pottery finds from the Pasikrata sanctuary, 1912 photo (source: AASA)

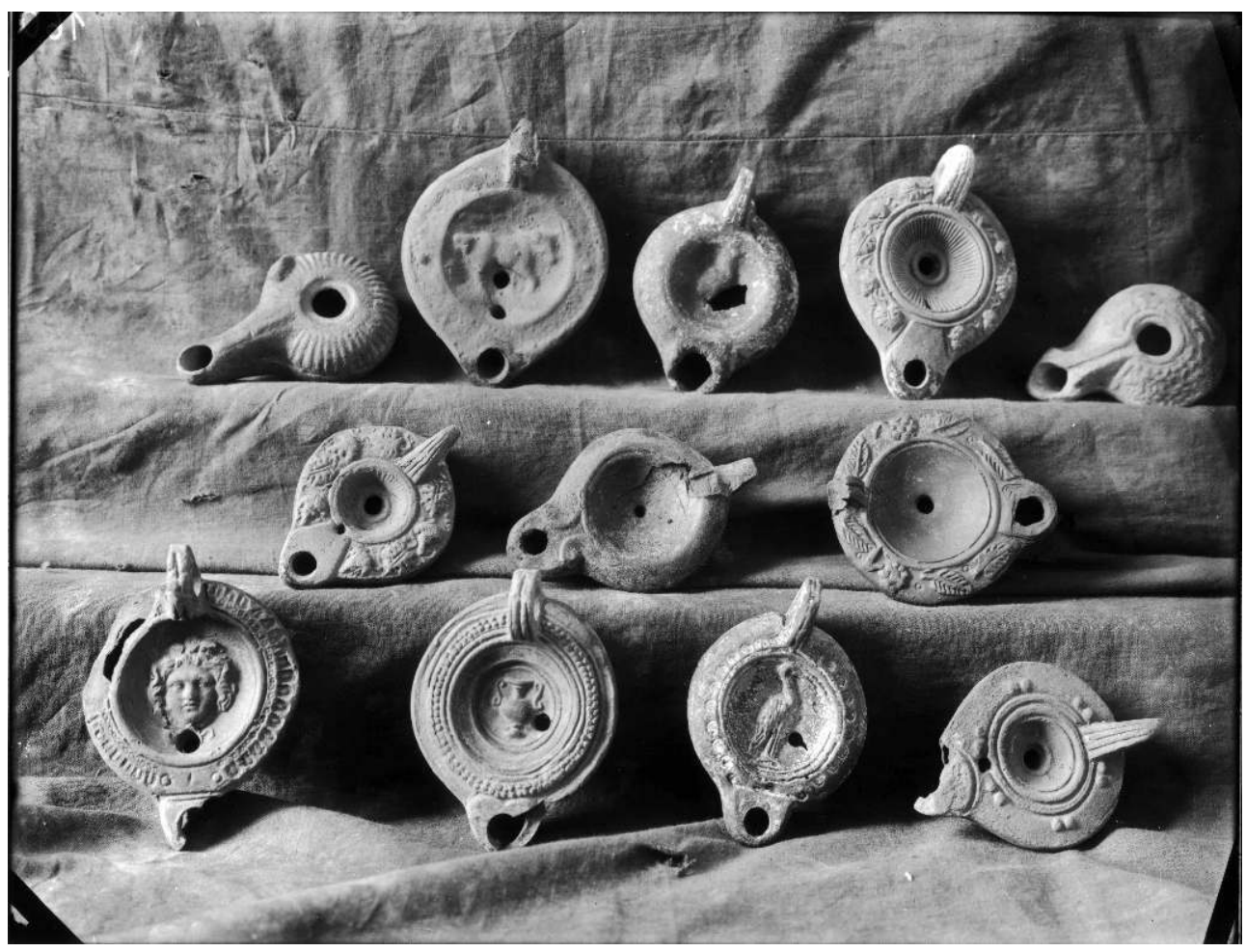

Figure 12

Lamps from the Pasikrata sanctuary, 1912 photo (source: AASA) 


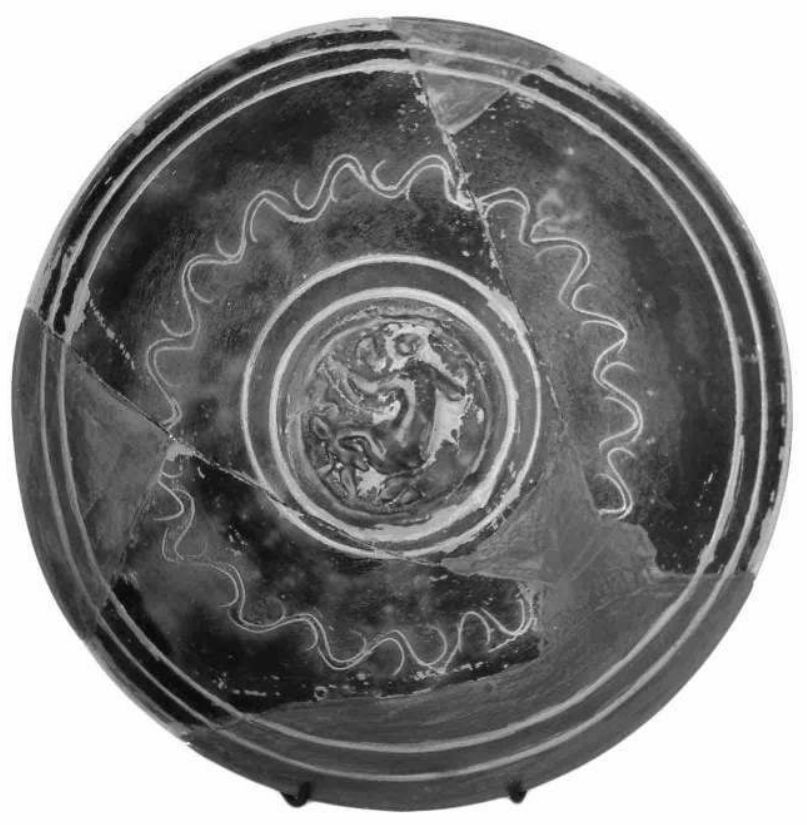

\section{Figure 13}

Clay West-Slope phiale from the Pasikrata sanctuary, Volos Museum K2291 (photo: author)

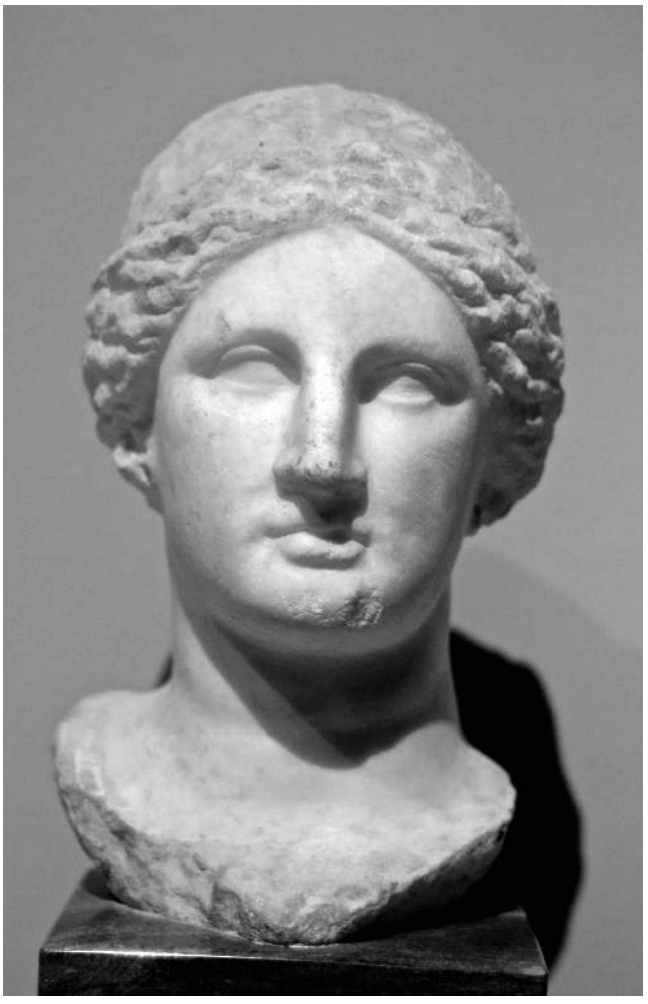

Figure 14

Marble head of a female goddess from the Pasikrata sanctuary, Volos Museum $\wedge 540$ (photo: author) 


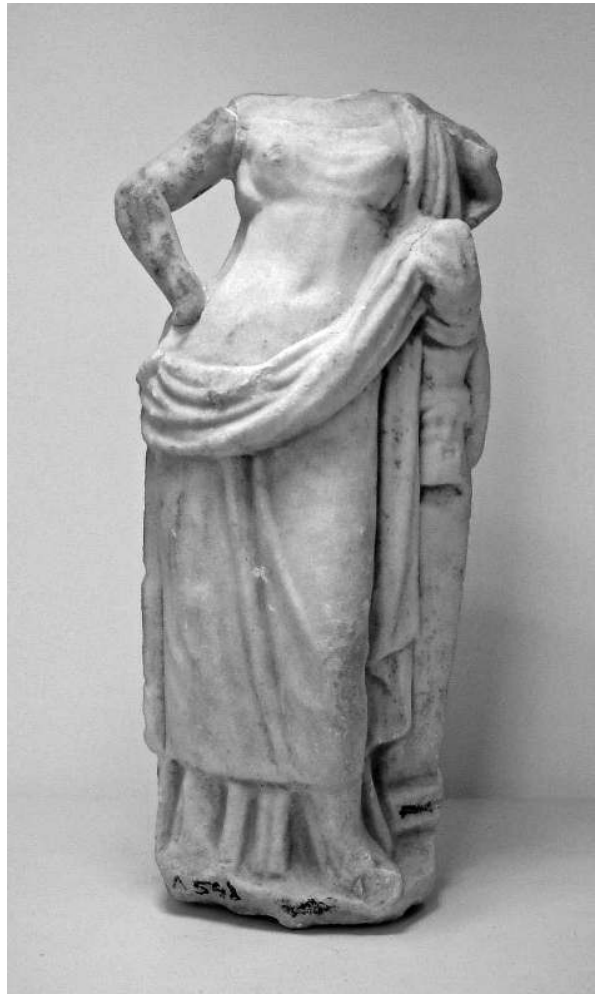

\section{Figure 15}

Marble head of a female goddess from the Pasikrata sanctuary (side view), Volos Museum $\wedge 540$ (photo: author)

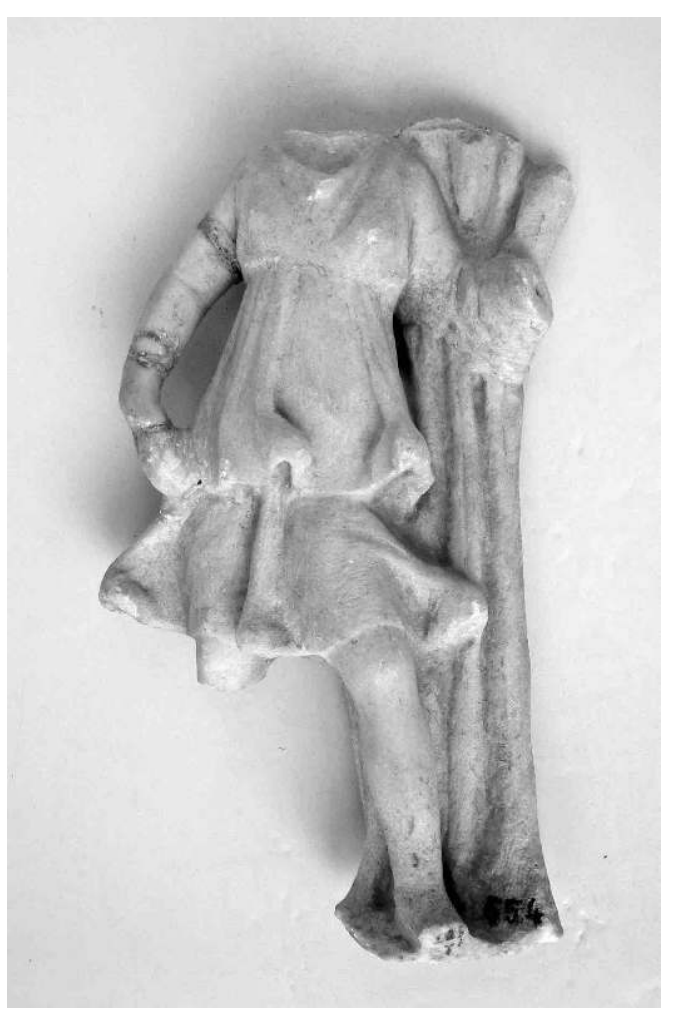




\section{Figure 16}

Marble statuette of Aphrodite with Eros, Volos Museum ^548 +^599 (photo: author)

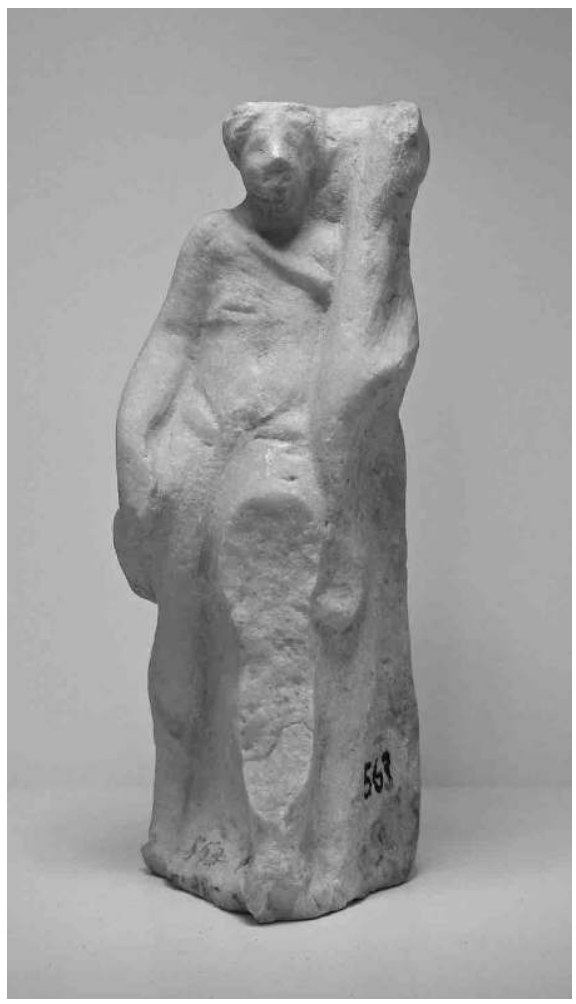

Figure 17

Marble statuette of Artemis, Volos Museum $\wedge 551$ (photo: author)

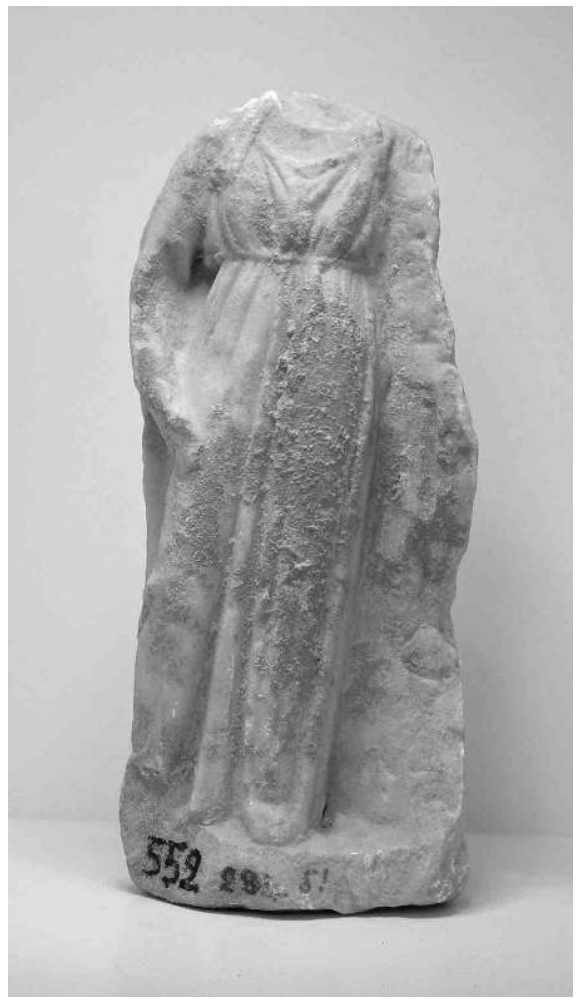




\section{Figure 18}

Unfinished female statuette, Volos Museum ^556 (photo: author)

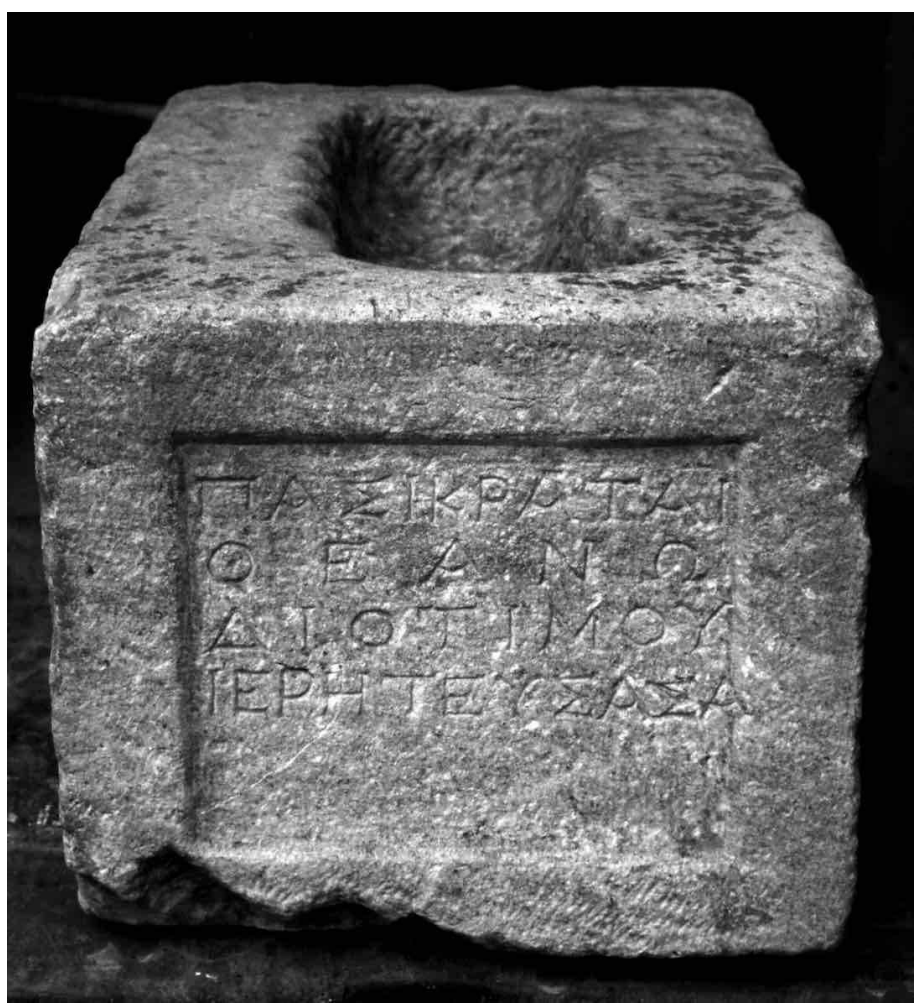

\section{Figure 19}

View of the marble base with the dedication by the priestess Theano, Volos Museum E827 (photo: author) 


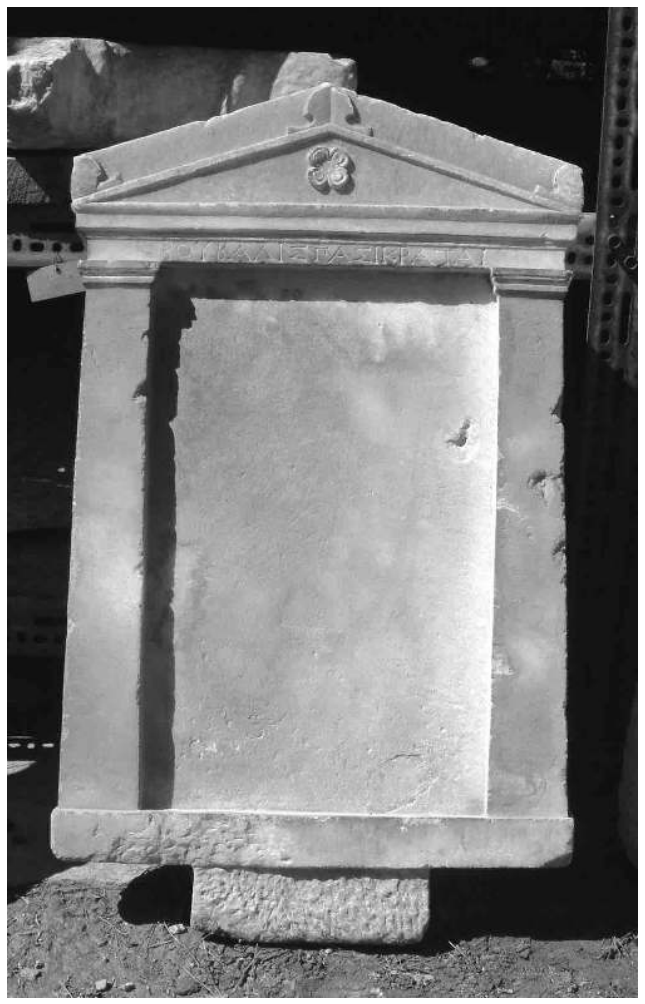

\section{Figure 20}

Marble naiskos stele dedicated by Boubalis to Pasikrata, Volos Museum E524 (photo: author)

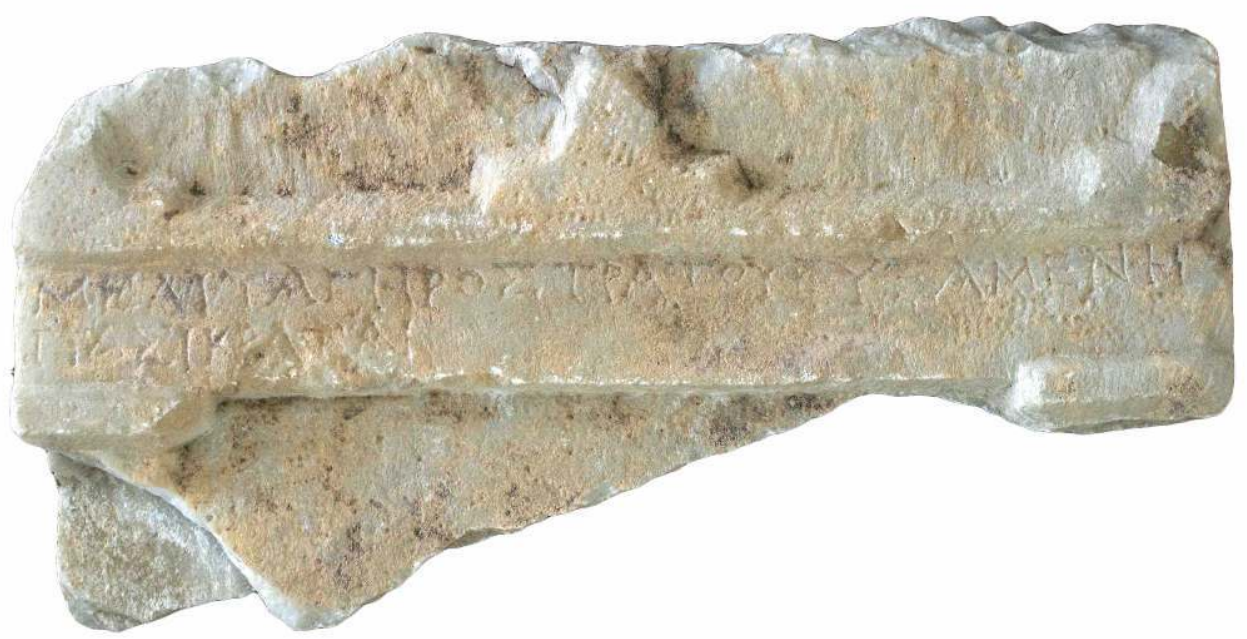

Figure 21

View of the naiskos stele dedicated by Melita, daughter of Gerostratos (photo: M. Kalaitzi). 


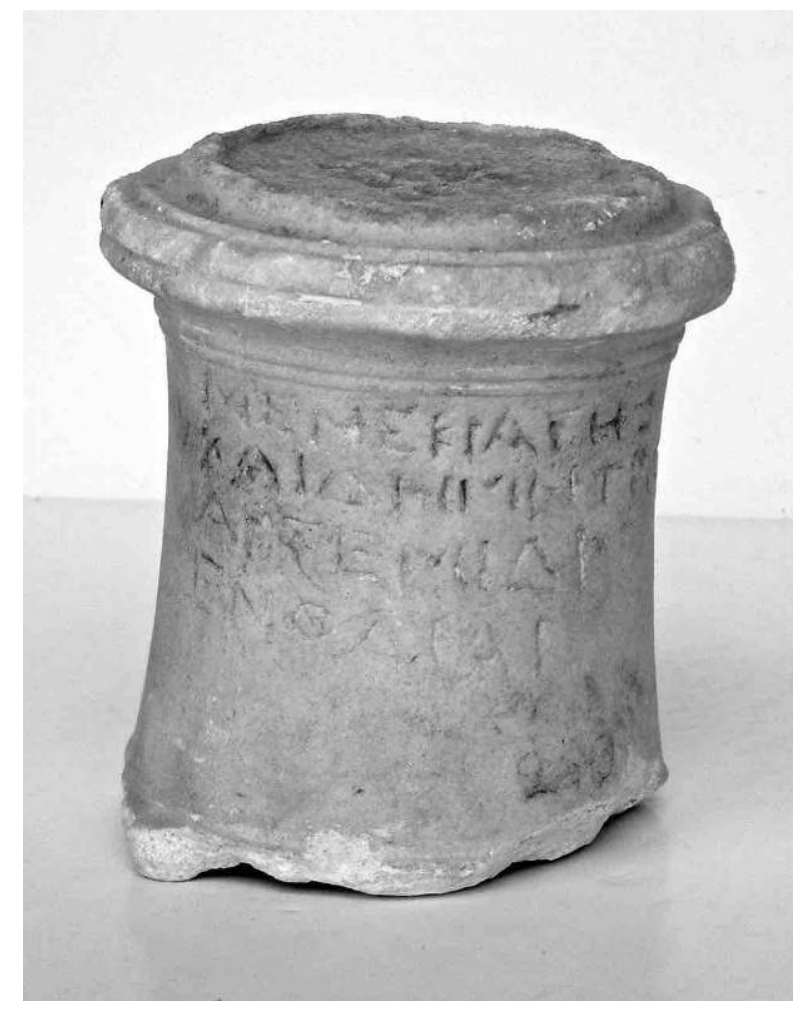

Figure 22

Marble cylindrical small altar/incense burner, Volos Museum (photo: author)

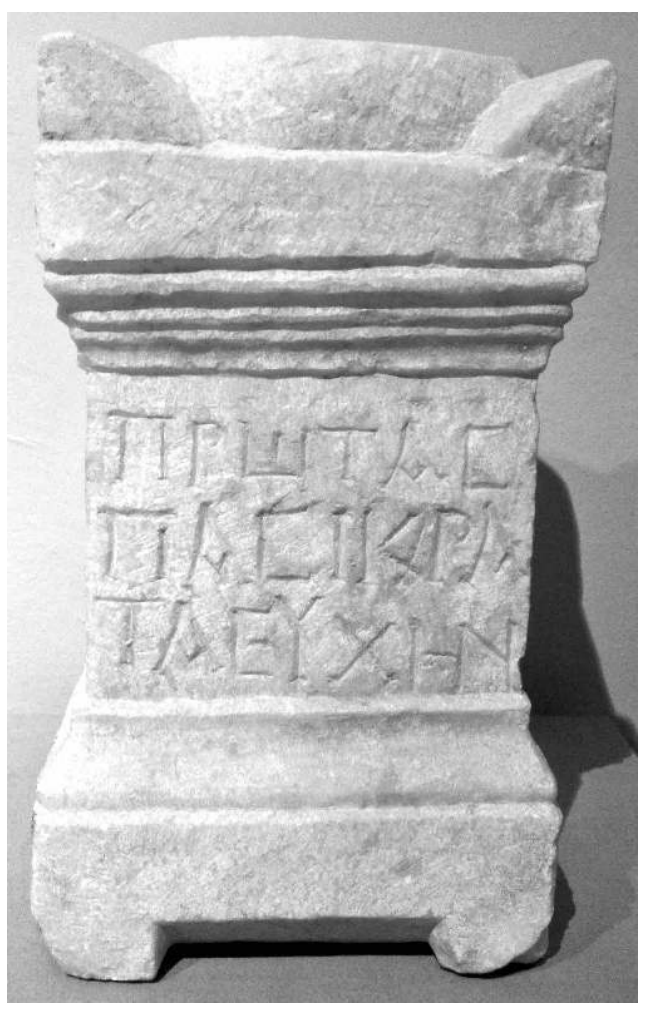

Figure 23

Marble cubic small altar bearing the dedication by Protas: Volos Museum E527 (photo: author) 


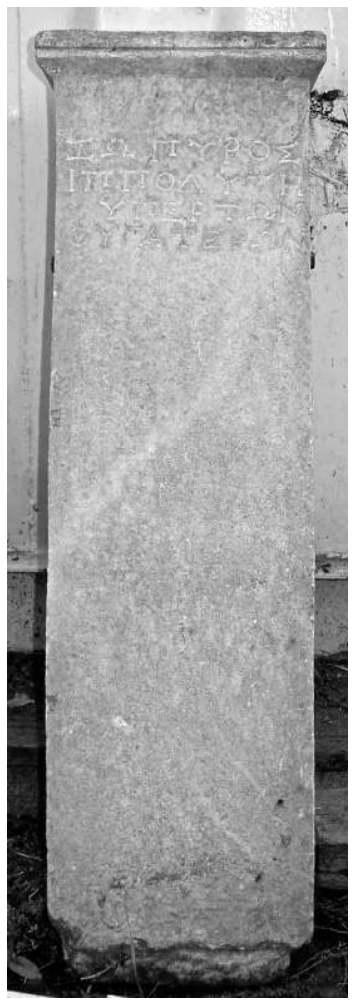

Figure 24

Votive stele bearing the dedication of Zopyros and Hippolyte: Volos Museum E537 (photo: author)

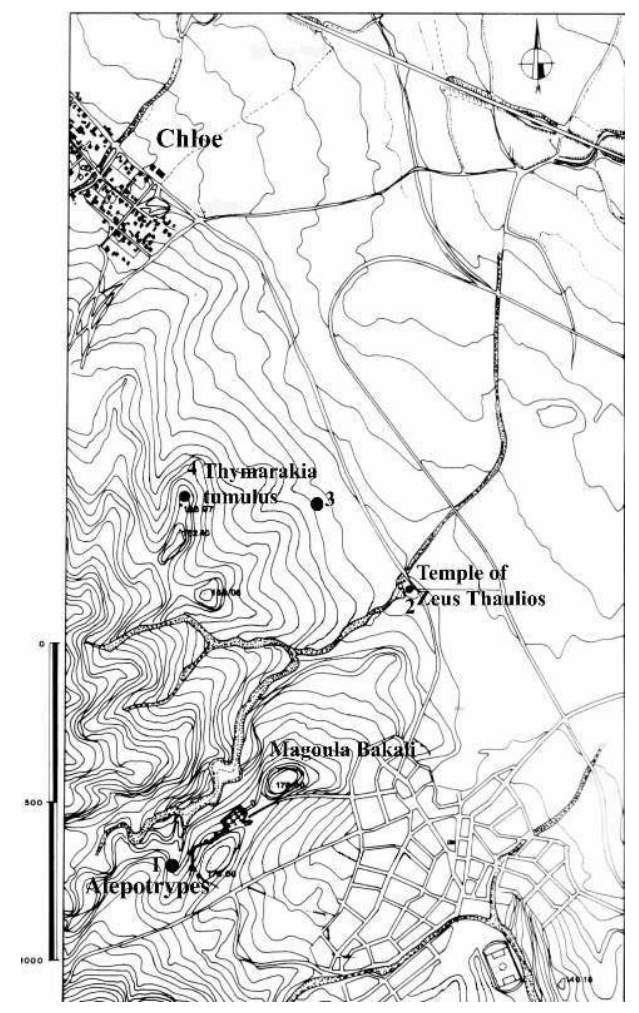

Figure 25

Map of Pherai (source: Arachoviti 1994) 


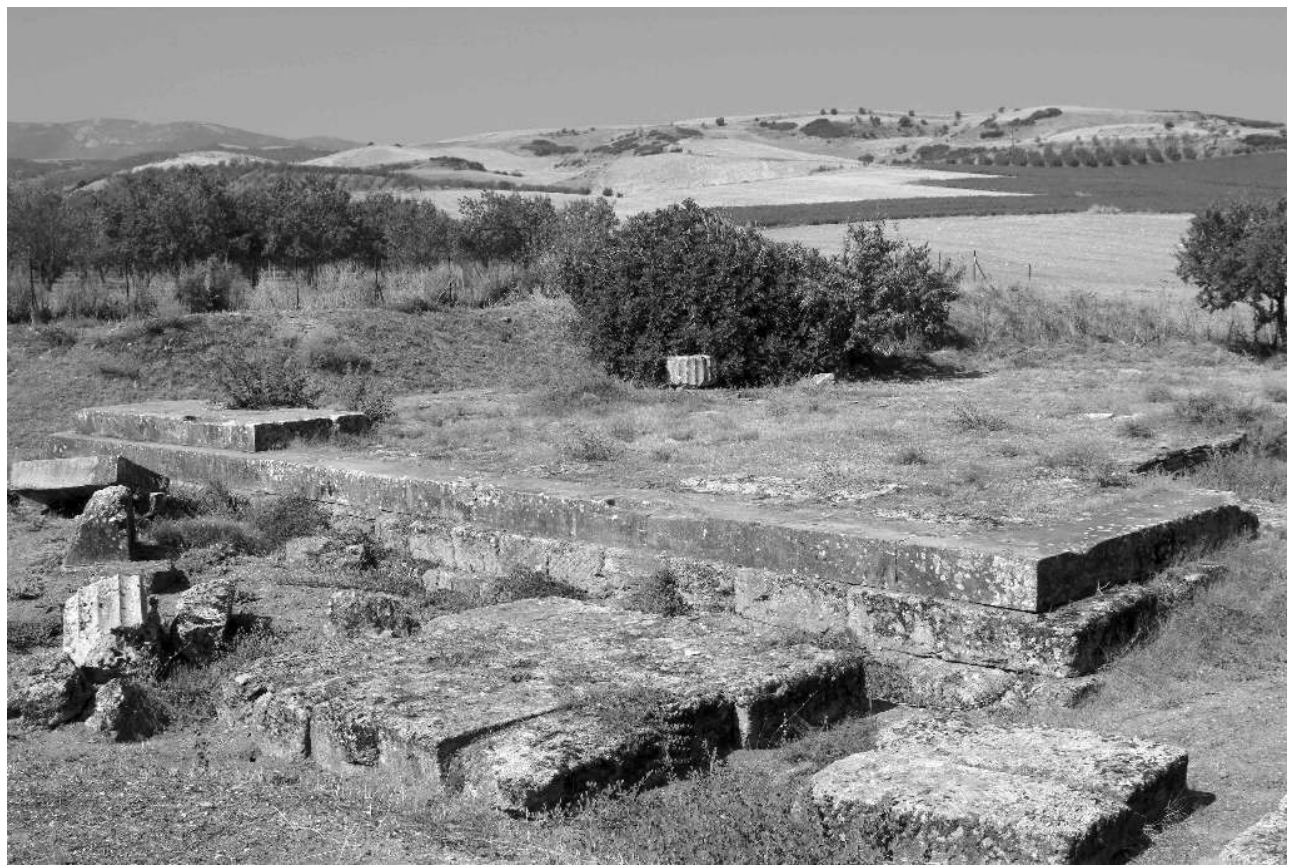

Figure 26

View of the Temple of Zeus Thaulios at Pherai (photo: author)

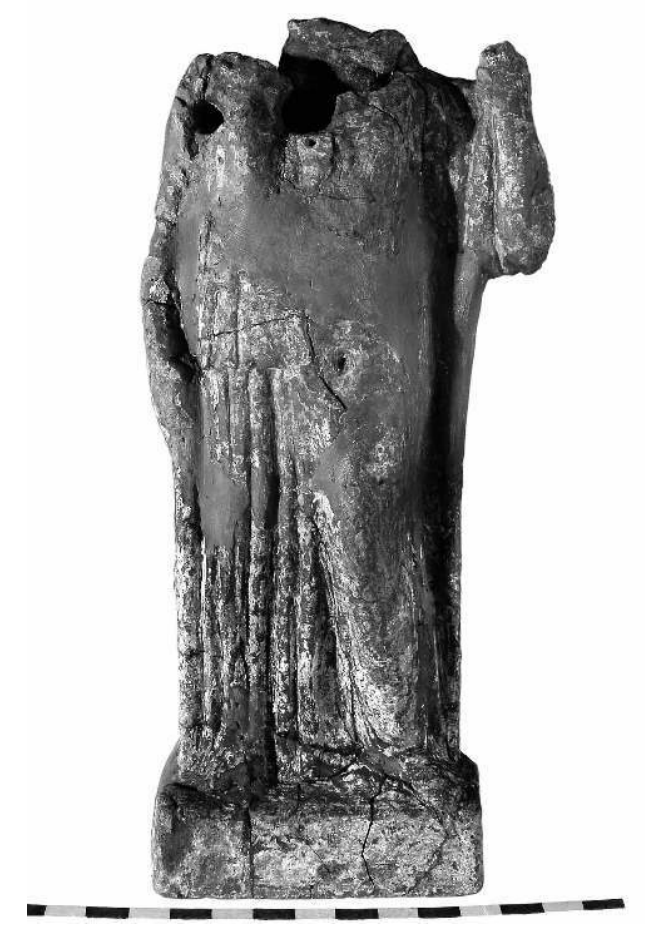

Figure 27

Clay figurine from the sanctuary at Alepotrypes at Pherai, Volos Museum BE 1628 (source: $13^{\text {th }}$ EPCA) 


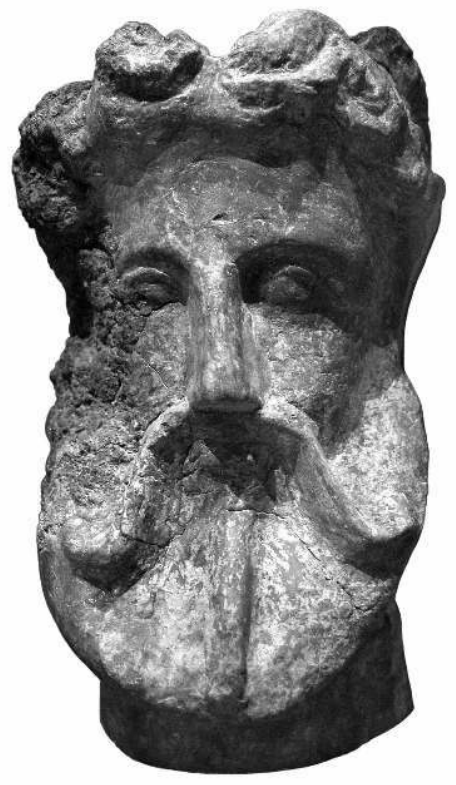

Figure 28

Clay male head from the sanctuary at Alepotrypes at Pherai, Volos Museum BE 1631 (source: 13 $3^{\text {th }}$ EPCA)

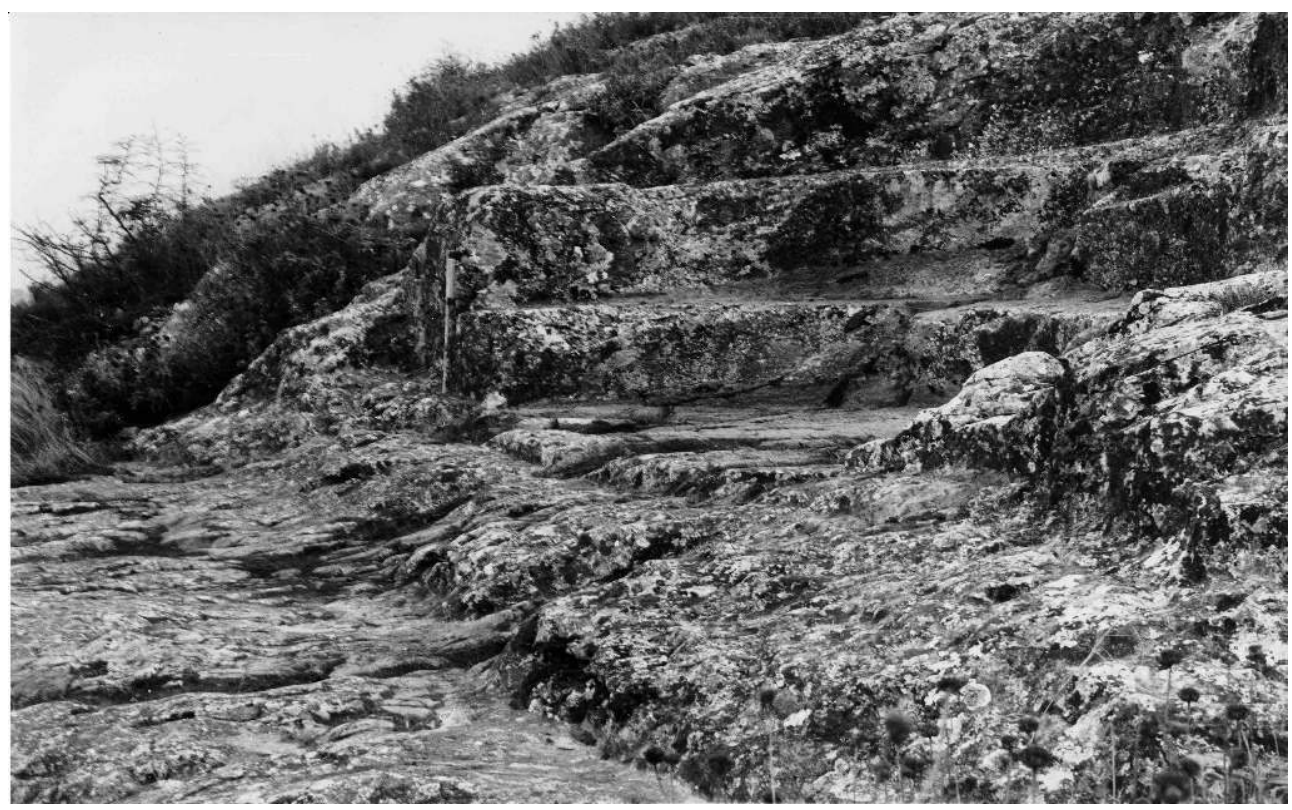

Figure 29

Stone rock-cut exedra in the northern cemetery of Demetrias (source: P. Marzolff) 


\section{Abbreviations}

\section{NOTES}

*. I would like to express my gratitude to the Board of the Archaeological Society of Athens and its Secretary General, V. Petrakos, for the permission to study and publish the excavations of A.S Arvanitopoulos in the sanctuary of Pasikrata and the cemeteries of Demetrias and for allowing me to use photographs and archive material for this article; to N. Kaltsas, former director of the National Archaeological Museum at Athens and to the $13^{\text {th }}$ Ephorate of Prehistoric and Classical

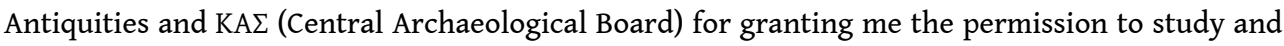
publish the finds from the Pasikrata sanctuary; the former directors of the Directorate of the National Archive of Monuments ( $\triangle \mathrm{EAM})$ P. Pantos and M. Tsipopoulou facilitated my research in the archives in every possible way. A. Matthaiou alerted me to the existence of Arvanitopoulos' archive in the Greek Epigraphic Society and offered very useful advice and invaluable practical help. Generous travel grants from the Shelby White-Leon Levy Program for Archaeological Publications, the Craven Committee, University of Oxford and the Zilkha Trustees, Lincoln College, Oxford made this research possible. I would also like to thank: A. Doulgeri-Intzesiloglou (Director, $13^{\text {th }}$ EPCA) for the permission to use photographs from the Alepotrypes sanctuary, V. Adrymi-Sismani (former Director, $13^{\text {th }}$ EPCA) for her support during my prolonged periods of study at Volos; A. Batziou-Efstathiou and P. Triantaphyllopoulou for sharing their expertise of 
Demetrias with me and for allowing me to study the archive of inscriptions from Arvanitopoulos' excavations that is kept in the Volos Ephorate (in 1997 and 2002); O. ApostolopoulouKakavoyianni, P.Arachoviti, B. Intzesiloglou and E.Skafida offered considerable practical support. Since 2010 I have conducted research in the National Archaeological Museum at Athens: Ch. Avronidaki, G. Kavvadias and A.Gadolou have helped me in all stages of this project. P. Marzolff very generously shared his knowledge of the topography of Demetrias with me during repeated visits to Heidelberg. M. Mili, G. Ekroth and A.-M. Leander offered useful suggestions on 'funerary sanctuaries' during presentations in 2003 and 2006 respectively. R. Parker, M. Melfi and S. Kravaritou read a first draft of this paper and made constructive comments. I warmly thank them all. All errors are of course the author's.

1. ARVANitopoulos (1912), p. 198-209; ID. (1915), p. 162-164, 187-191; ID.,AD 1 (1915), Parartema p. 5658, esp. 56-57; ID. (1920), p. 21-25; ID. (1921), p. 35-36; GrStelai, p. 42-48.

2. ARVANITOPOUlOS (1912), p. 203, fig. 14; ID., GrStelai, fig. 49.

3. ARVANitopoulos (1912), p. 201-205, fig. 15; ID., GrStelai, fig. 48.

4. Also: PuD, p. 47-48, 123, 188; PAPACHATZis (1958); StAMATOPoulou (1999), p. 203-206, pl. 60-66.

5. Until recently only a small part of the finds were inventoried as coming from the Pasikrata sanctuary (HORNUNG-BERTEMES [2007], p. 26, 41-42). The photographs in the archives of the Archaeological Society of Athens were of crucial importance for the identification of the finds in Volos and Athens. Work in Volos took place in 2002-3; with the exception of nearly 30 figurines all others had been mostly recorded as of unknown provenance. Of the nearly 70 figurines that were identified in the Volos Archaeological Museum storerooms as originating from the Pasikrata sanctuary, most were part of the former private collection of M. Apostolides, friend and sponsor of Arvanitopoulos. Work in Athens started in earnest in spring-summer 2010, when four boxes of un-inventoried antiquities from Arvanitopoulos' excavations were located. These contained hundreds of fragments of figurines and relief moldmade bowls from Demetrias, Phthiotic Thebes and other sites. The finds are still under conservation and study. I would like to thank Ch. Avronidaki and G. Kavvadias, who alerted me to the existence of these boxes, and for all their practical help.

6. GrStelai, p. 45.

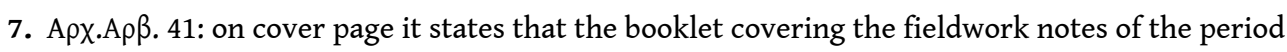
23 June - 26 November 1912 was lost in Sorovits.

8. I would like to thank P. Marzolff for discussing with me the topography of this part of Demetrias and the changes that have occurred in the area in the last fifty years. MARZOLFF (1980), p. 9, n. 7 .

9. ARVANitopoulos (1912), p. 210, fig. 21.

10. Based on the daybooks in the AASA, Apx.Apß. 43-44; GrStelai, p. 62.

11. As is evident from his excavation daybooks, Arvanitopoulos found clay figurines of similar type at various places in the vicinity of the Pasikrata deposits, for example in the excavations of the $5^{\text {th }}$ Stelai tower but also on the surface and among graves: ARVANITOPOULOS (1912), p. 206; GrStelai, p. 44-45, 48 (for the figurines found at deep levels in the extension of the $5^{\text {th }}$ Stelai tower). Similarly, a tomb found near the Pasikrata sanctuary allegedly contained many clay figurines of similar type to those found in the pits: ARVANITOPOULOS (1915), p. 187; AASA, ApX.A $\beta$. 44: 6-8 Iouvíov 1915. It is thus not certain that all figurines illustrated in his various publications were actually found in the pits; some could have originated from graves: HORNUNG-BERTEMES (1997), p. 185-186. For figurines from the cemeteries of Demetrias: BATzIOU-EFSTATHIOU TRIANTAPHYLLOPOULOU (2003-2009), p. 226, no. 5: grave 11 (northern cemetery), p. 314-315; also: NIKOLAOU (2009). 
12. ARVAnitopoulos (1920), p. 23-24; he changed his mind in GrStelai p. 48. On 'votive' deposits, the problems of identifying the character of a pit in a sanctuary, and the importance of context, see recently PATERA (2012), p. 102-107, 192-194, 215.

13. PAPACHATZIS (1958), p. 54-55.

14. CHONDROGIANNI-METOKI - MAGGOURETSIOU (1999) for deposits containing figurines, busts, incense burners and lamps probably belonging to a sanctuary at the locality Kato Bravas Velventou; CHRYSSANTHAKI-NAGLE (2006), p. 17, n. 72 relates them to a cult of the Nymphs or the Muses alongside the main cult which could be of Zeus Hypsistos. Similarly, a large deposit (measuring $6 \times 7 \mathrm{~m}$ ) was recently discovered near the torrent Ag. Symeon of the village Ag. Thomas Mesologgiou; it contained 15,000 fragments of figurines and pottery. Among the figurines were images of Artemis, Kerberos and others related to Demeter and Kore. Architectural remains that most likely belong to a sanctuary are located in the vicinity but have yet to be investigated. The shrine belonged to the Aetolian city Alikyrna that extends on the

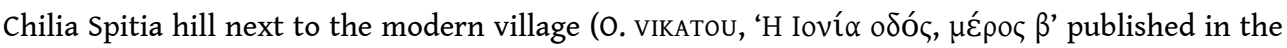

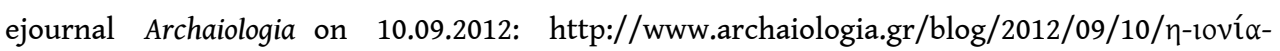
oঠó $\varsigma-2 /)$.

15. UHLENBROCK (1988), p. 126.

16. AD 44 (1989), Chronika p. 188-190, pl. 112 (Salonon St).

17. It is often the case that architectural remains in shrines of Demeter and Kore are not monumental in scale, for example in Demetrias: BATZIoU-eFstathiou (2010), p. 182-183; Rhodes: GIANNIKOURI (1999); Pella: LILIBAKI-AKAMATI (1996). On sanctuaries of Demeter: COLE (1994); PATERA (2012), p. 231-248.

18. HINZ (1998), p. 102-107, esp. 103 for the temple foundations. The area at Piazza della Vittoria was used as a necropolis in the Archaic and Early Classical periods and graves continued to the end of the $5^{\text {th }}$ century, the period when cult at the shrine began. For a recent discussion of the shrine and the significance of the discovery of the crater with the dedicatory inscription to Artemis Pheraia: FISCHER-HANSEN (2009), p. 212; PARISI (2010), p. 458-459; PALAIOTHODOROS (2009).

19. See above n. 11. Also HINZ (1998), p. 206-207, for changes at the temenos wall M2 in the sanctuary at Contrada Parapezza at Locri, a Thesmophorion, around the mid- $4^{\text {th }}$ century during the enlargement of the walls and the foundation of a tower there.

20. GrStelai, fig. 52-55.

21. HORNUNG-BERTEMES (2007), p. 41-42; o.c. (n. 5). The extremely fragmentary condition of the figurines recently identified in Athens is explained in a report by K. Rhomaios addressed to the Ministry of Education, no. 915 of 1.3.1926: STAMATOPOULOU (2009), p. 21 n. 39.

22. HORNUNG-BERTEMES (1997) on the figurines of the boys with kausia; EAD. (2007), ch. 5; BATZIOUEFSTATHIOU (2010), p. 190; JENSSEN (2007), p. 167-174, esp. 168-169.

23. GrStelai, fig. 55 .

24. Volos Museum M2001: GrStelai p. 58, fig. 77ү; HORNUNG-BERTEMES (2007), p. 164, no. 227, and Taf. 31; BAtZiou-efstATHiou (2010), p. 189, no. 2, and fig. 8.

25. Large-scale clay sculpture was also discovered in another sanctuary site of Demetrias, the socalled Thesmophorion, where remains of a head belonging to a female statue ( $\mathrm{Pr} . \mathrm{H}: 0.24 \mathrm{~m}$ ) came to light: BAtZiou-efstathiou (2010), p. 182-183, no. A, and fig. $4 \alpha-\beta$. From the same excavation we should note the discovery of a mold for the production of terracotta plaques bearing a Dionysiac scene: BATZIOU-EFSTATHIOU (2010), p. 184, fig. 5. In recent years a number of large busts, bearing elaborate hairstyles and dress have been found in houses of Demetrias: BATZIOU-EFSTATHIOU triantaphyllopoulou (2000); P. triantaphyllopoulou, AD 55 (2000), Chronika, p. 466-468 (Katsiphas' property). For large-scale clay statues in sanctuaries: вооКIDIs (2010) mainly on Corinth but discussing other sites on p. 273-274; also JENSEN (2011), p. 150-151, fig. 127, for an almost-life-size clay female bust of Hellenistic date from Kalydon. 
26. Volos Museum M2002, M2004: HORNUNG-BERTEMES et al. (1998), p. 199; EAD. (2007), p. 172-173 nos. 266-267.

27. Doulgeri-InTZesiloglou (1992), p. 438 (Pherai); V. RONDIRI, AD 52 (1997), Chronika, p. 485-486 (Metropolis).

28. Essentially the only pots identified with certainty are those illustrated in ARVANITOPOULOS (1912).

29. GrStelai, fig. 56-57. For lamps in sanctuaries: PARISINOU (2000), p. 143-145 (Thesmophoria).

30. Volos Museum K2291: stamatopoulou (1999), pl. 63d. An identical phiale was discovered in the so-called Metroon of Demetrias; it was presented by A. Batziou on 1.12.2012 during the Conference Sanctuaries and Cults in Ancient Thessaly (in Athens, British School at Athens).

31. Volos Museum $\Lambda 540$ (H. 0.39 m): GrStelai fig. 51; A. DeLIVorRIAS, s.v. Aphrodite,LIMC II.1 (1984), p. 107 , cat. no. 1063, who attributes it to an over life-size seated statue, and notes that the identification of the divinity relies on the nature of the sanctuary.

32. S. Psoma has brought to my attention the similarity of the Demetrias head to the image of Artemis on the obverse of the coinage of Orthagoreia (which she identifies with the predecessor of Maroneia): PSOMA - KARAdiMA - TERzopoulou (2008), p. 194-204, esp. 197, 202-3 for the hypothesis of a cult of Artemis Orthagoreia aiming to protect young males approaching puberty. At Kalydon an over life-size marble female head wearing a mural crown that belonged to an acrolithic statue of a seated female deity was found in the 'cult room' of a peristyle building, which has been tentatively identified as a clubhouse; the identification of the deity portrayed with Meter relies on the context: JENSEN (2011), p. 137-140, fig. 115-118; DIETZ (2011a), p. 134-135 and fig. 113; DIETZ (2011b).

33. Volos Museum $\Lambda 548+\Lambda 599$ : Delivorrias l.c. (n. 32), p. 45 s.v. Aphrodite, cat. no. 337.

34. Volos Museum $\Lambda 551, \Lambda 563$ : chrysostomou (1998), p. 191-193, pl. 29;stamatopoulou (1999), pl. 64.

35. Volos Museum $\Lambda 556$ : STAmatopoulou (1999), pl. 64.

36. ARVANitopoulos (1920), p. 22 for a list of the inscribed monuments. Also AD 17 (1961/1962), Chronika p. 178, (= Volos Museum E719) for an epitaph of Pasikrateia (?). For the latter see also: BATZIOU-EFSTATHIOU (2010), p. 188.

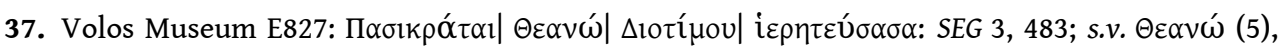

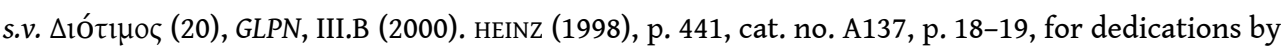
priests/priestesses in Thessaly. For Theano as a name for priestesses: CONNELLY (2009), p. 11.

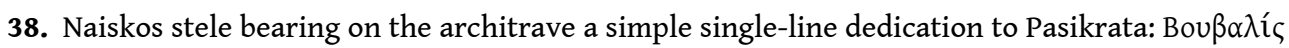

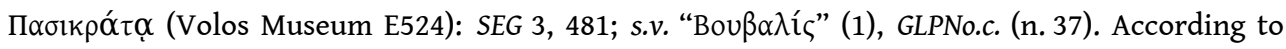
Arvanitopoulos, GrStelai, 44, the stele was found almost at surface level. See also: HEINZ (1998), cat. no. 298, fig. 164; stamatopoulou (1999), pl. 66a. The name is also attested on a tombstone from Demetrias: Volos E366 (Boubalis, daughter of Epikrates from Athens).

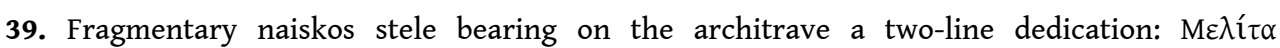

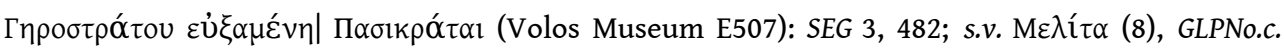
(n. 37). Also: HEINZ (1998), cat. no. 299. Unpublished photograph in the AASA, no. 3777 (upper left corner).

40. Small cylindrical altar bearing a four-line dedicatory inscription to Artemis Enodia dated to

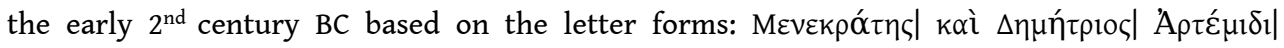

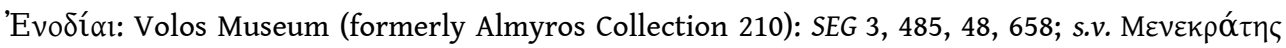
(60), GLPNo.c. (n. 37); HEINZ (1998), cat. no A67; chRYsostomou (1998), p. 191-2, pl. $26 \beta$.

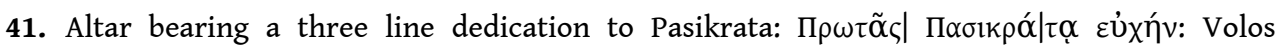
Museum E527: GrStelai, fig. 50; s.v. П $\omega \tau \tau \tilde{\alpha} \varsigma$, GLPNo.c. (n. 37). For the meaning of the dedicatory formula: VAN STRATEN (1981), p. 70-72; PATERA (2012), p. 47-51. 


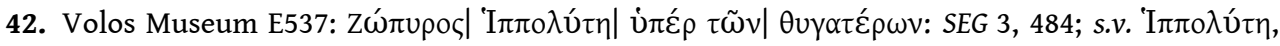

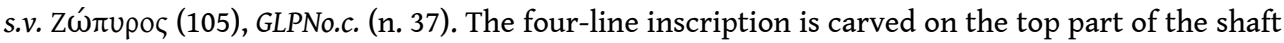
of the stele; the letters of the last line are accentuated with red colour. HEINZ (1998), p. 440-441 cat. no. A136.

43. HEINZ (1998), cat. no. 340, fig. 288. To my knowledge there is no conclusive evidence to confirm such an attribution.

44. A number of clay altars were found in the sanctuary, for example Volos Museum K1205 (Fig.11, top row $2^{\text {nd }}$ from the left). ARVANitopoulos (1912), p. 201, mentions among the finds very elaborately decorated clay altars/incense burners. There are three examples in the Volos Museum, of unknown provenance, that could fit such a description (Volos Museum K1887K1889). However, identification has to remain tentative.

45. As is suggested by the relatively large number of lamps recovered from the site.

46. PARKER (2005), p. 438-439; R. PARKER, s.v. "Dedications", C. Formulae of dedication, ThesCRA I (2004), p. 274-276, for the meaning of the dedicatory formulas; also HEINZ (1998), p. 25-26; GARCíA RAMÓN - HELLY (2007), p. 287.

47. WilAMOWITZ I (1932), p. 108; ROBERT (1936), p. 134-135; ViKela (1994), p. 67-78; EAD. (2011), p. 151; VOUTIRAS (1999), p. 80-81; MILI (2005), p. 286, n. 1126. See also on the epiclesis Epikrateia preserved on a statue base, dated to the $3^{\text {rd }}$ century $\mathrm{BC}$, from the sanctuary of Artemis at Drymonas Archontochoriou: KOLONAS (2004); SEG 55, 593.

48. aRVAnitopoulos (1920), p. 22-24. Also PuD, p. 188.

49. PAPACHATZIS (1958), p. 53-62; ID. (1984), p. 149; CHRYSOSTOMOU (1998), p. 95-96, n. 1059; HELLY (2010), p. 58; BAtziou-efstathiou (2001), p. 33; EAD. (2010), p. 188-192; hatzinikolaou (2010), p. 216-217; EAD. (2011), p. 127-128. In PuD, p. 188, they stress the importance of the location of the sanctuary by roads and the gate to the harbour, while HEINZ (1998), p. 84-85 links Pasikrata to the circle of great eastern mother goddesses, like Meter Theon and Atargatis.

50. PAPACHATZIS (1958), p. 62.

51. Plutarch, Quaestiones Romanae, 269b; PIRENNE-DELFORGE (1994), p. 299-301, 384, 442.

52. Examples: DROUGOU, TOURATSOGLOU (1980), p. 169-173, 181-182; TZANAVARI (1987), p. 866-867; AD 39 (1984), Chronika p. 260-261 (Veroia); Mieza: MisAeLIDou-DESPOTIDOU (1990); Vergina/Aigai: KOTTARIDI (1990), p. 37 (grave K3); Pella: LILIBAKI-AKAMATI (1989), p. 95-97; EAD. (1994), p. 214-238; Abdera: SAmiou (1988). Also, Achinos: AD 43 (1988), Chronika p. 213 (Voreiou Epeirou st., grave 1); 47, (1992), Chronika p. 191-192 (acropolis hill grave 1); Eretria: HUGUENOT (2008), p.177-178. For an alternative interpretation of Erotes as daemons: HUGUENOT (2001).

53. For the impact of the Macedonian control of Magnesia and the synoecism that created Demetrias on the ritual space of Demetrias see: KRAVARITOU (2011), EAD. (forthcoming).

54. CHRYSSANTHAKI-NAGLE (2006), p. 19, n. 101-102.

55. снrysostomou (1994a), p. 65; ID., AD 49 (1994), Chronika p. 538 (Macedonian Tomb $\Gamma$ at Pella); also recently: HATZINIKOLAOU (2011), p. 78.

56. On the meaning of female protomai: UHLENBROCK (1988), p. 139-142, 150-156; CHRYSSANTHAKINAGLE (2006), esp. p. 24-28; MULLER - TARTARI - TOÇI (2004), p. 619-620; MULLER (2009); TARTARIet al. (2010), p. 3-4, who refute an association with a specific deity/ies, let alone with 'chthonic'-funerary ones; MITSOPOULOS LEON (2009), p. 18-20, esp. 20; PARISI (2010), p. 461; KATAKOUTA (forthcoming).

57. A good overview of the Macedonian evidence in CHRYSSANTHAKI-NAGLE (2006), p. 18-21.

58. SOURVINOU-INWOOD (1991), p. 147-188; HINZ (1998), p. 203-207; DILLON (2002), p. 222-228, 233; RIEDWEG (2003), p. 210-214, 222, 352-354, 368; PARKER (2011), p. 227-232.

59. There is also a dedication to a Pasikrata by a certain Lykainis on a lamp dated to the $1^{\text {st }}$ century AD: ROBERT (1936), p. 134-135, no. 88, pl. XLVII; SEG 37, 1526; 49, 740. 
60. ZUNTZ (1971), p. 97-108, esp. 103; DE POLIGNAC (1995), p. 111-113; JAMESON et al. (1993), p. 81-103; HINZ (1998), p. 144-152; VONDERSTEIN (2006), p. 199-213, esp. 202-208; GROTTA (2010), esp. p. $176-$ 179 and n. 246.

61. Arta Archaeological Museum inv. 26: DRAGoumis (1910); tzouvara-SOUli (1979), p. 20; EAD. (1992), p. 161-2: marble stele preserving the dedicatory inscription by Nikandros, son of Solon; the upper part of the stele was worked to receive a statue. Date: $1^{\text {st }}$ half of $2^{\text {nd }}$ century BC. The stele was found in the cemetery area of Ambrakia, by the banks of river Arachthos, in second use. QUANTIN (2010), p. 432-433, links the stele with a statue found in the vicinity.

62. Ioannina Museum, inv. 5054: SEG 37, 528; VOKOTOPOULOU (1971); TZOUVARA-SOULI (1979), p. 28; PLIAKOU (2010), p. 414-415; QUANTIN (2010), p. 434.

63. ROBERT (1940), p. 73-74; DÜLL (1977), p. 116-118, 381-381; SEG 32, 636; SEG 49, 740;IG X 2, 2 , 1. 18A-18C; CHATZINIKolaou (2011), p. 127-128; FALEZZA (2012), p. 180. HATZOPOUlos (1994), p. 113-119 for a link of gods guaranteeing manumissions in Macedonia to initiation rites of young persons.

64. On votive offerings and their relation to the venerated deity: VAN STRATEN (1990); MITSOPOULOS-LEON (2010), p. 413; PLIAKOU (2010), p. 417-418; PARISI (2010), p. 461; MERKER (2000), p. 232-234 (focusing on figurines); sCHIPPOREIT (2013), p. 211-216; also MILI (2005), p. 145-47 for Thessaly.

65. AD 28 (1973), Chronika p. 345-346, pl. 309 ß- $\gamma$; MARZOLFF (1980), p. 31, 54; HORNUNG-BERTEMES (1997), p. 197-200; EAD. (2007), p. 39-41. I would like to thank Dr. P. Marzolff for showing me the photographs from their investigations in the area of Hill-35 and Dr K. Hornung-Bertemes for discussing the site with me.

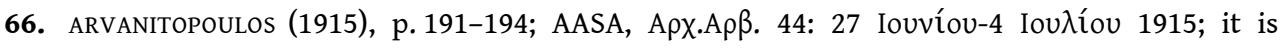
possible that some of the figurine and pottery fragments recently found in the National Archaeological Museum in Athens come from Arvanitopoulos' 1915 excavation. On the 'Thesmophorion': DAFFA-NIKONANOU (1973), p. 21-22; HEINZ (1998), p. 70-71; KRAVARITOU (2011), p. 122 and BAtZIOU-EFSTATHIOU (2010), p. 179-188, for recent excavations on the site. The location of the sanctuary of Demeter, Kore and Plouton near the fortification wall on the eastern sector of the city finds close parallel in Rhodes: GIANNIKOURI (1999). For the location of sanctuaries of Demeter just outside the fortifications of cities: COLE (1994), esp. p. 204-214; EAD. (2004), p. 50-52 (with regards to the Thasos Thesmophorion).

67. The figurines show a general interest in women, youths and children and do not seem to reflect specifically to details of cult/events of the sanctuary; see MITSOPOULOS-LEON (2010), p. 413 for Brauron (contrary to Lousoi where more cult-specific figurines have been identified); PLIAKOU (2010), p. 417 for Epirus; MERKER (2000) for the sanctuary of Demeter and Kore in Corinth; SCHIPPOREIT (2013), p. 211-214 for sanctuaries of Demeter and Kore in Ionia.

68. Pingiatoglou (1981), p. 91-92; WiSE (2007), p. 29; see also discussion in MERKER (2000), p. 169170,331 for the role of Aphrodite in the sanctuary of Demeter and Kore in Corinth.

69. En(n)odia used as an epithet of Artemis is also attested at Pherai: GARCíA RAMÓN - HELLY (2007), p. 279, 289-290, propose an assimilation of local En(n)odia with panhellenic Artemis. Whether she should be considered as a separate deity from En(n)odia, as CHRYsostomou (1998), p. 206 proposes, or not, is beyond the scope of this study: cf. L. KAHIL, s.v. Artemis (Artemis Enodia), LIMC II.1 (1984), p. 687-689. PARKER (2005B), esp. p. 223; ID. (2011), p. 68-70 on cultic double names.

70. On En(n)odia: cHRYsostomou (1998), who however should be used with caution, especially in his discussion of literary evidence; ID. (2008) for the most recent evidence. In CHRYsostomou (2002), p. 209 he explains the epiclesis stathmia attested for En(n)odia in Larisa, as protector of gates; HEINZ (1998), cat. no. A70. Also: A. MOUSTAKA, s.v. Enodia, LIMC III.1 (1986), p. 743-744; HEINZ (1998), p. 64-66, 139-140. 
71. For the alleged distinction between Olympian and Chthonian gods and the debate on the usefulness of this distinction: SCHLESIER (1991-1992); EAD. (1994); PARKER (2011), p. 80-84, who do not think that the distinction is helpful or that it captures the essence of Greek ritual action. Contra: BURKERT (1985), p. 199-203; HENRICHS (2005); SCULLION (1994); ID., (2005); VOUTIRAS (1999), esp. p. 73-4, and recently PATERA (2012), p. 203-206.

72. KRAUS (1960), p. 77-83; recently HELLY (2010) and ZOGRAFOU (2010), p. 114-115.

73. MILI (2005), p. 250-258, 287 (seeing her as a deity that 'seems to have brought prosperity and protection to the family'); GRANINGER (2009).

74. снrysostomou (1998), p. 42-48 (Pherai), 59-60 (Atrax), 67 (Gonnoi); also recently Helly (2010). 75. BÉQUiGNON (1937); CHRYSOSTOMOU (1998), p. 25-47.

76. Thirty-eight Protogeometric graves were discovered under the foundations of the temple: CHRYSOSTOMOU (1998), p. 35-38. MORGAN (1997), p. 170-174; EAD. (2003), p. 135-139 has hypothesized (following Kalligas) that there had been a tumulus above the graves and - based on the significance of fibulae for fixing funerary clothing - has interpreted the large percentage of fibulae among the early votives as a symbolic link between funerary and votive contexts.

77. VON GAERTIGEN (1911); SOLMSEN (1911), p. 286-291; H. SCHWABL, “ZEUS I.EPIKLESEN”,RE 10A (1972), p.315; Béquignon 1937, 87-88; ID., “zeus”, RE Suppl. 15 (1978), p.1107-1111; DECOURT (1991); CHRYSOSTOMOU (1998), p. 236-243.

78. For recent investigations in the sanctuary: ARACHOVITI - DOULGERI-INTZESILOGLOU - TSIGARA (2009).

79. The course of the walls here has not been confirmed via archaeological investigation.

80. If one applies the de Polignac model (which however has been shown not to be the factor behind the location of suburban sanctuaries near many sites) the location of the sanctuary at the edge of Pherai could reflect a wish of the inhabitants of the settlement to delineate the borders of their territory: DE POLIGNAC (1995), p. 20-24.

81. MAZARAKIS AINIAN (1997), p. 39.

82. MAZARAKIS AINIAN (1997), p. 276-283, 351-352; ID. (1999), p. 10, 23. THOMPSON (1968), p. 58-60; LALONDE (1968) for the shrines at the SW corner of the Athenian Agora, near earlier graves. PARKER (1996), p. 33-36, proposed that the cult was in honour of anonymous heroes, collective ancestors. Also: ANTONACCIO (1995), p. 199-220; WHITLEY (1994), p. 217-218, 225 (Attica).

83. MILI (2005), p. 74, 211-212, 250-258.

84. As for example at Prodromos, see below p. 219-220.

85. BÉQUIGNON (1964), p. 400-412: SEG 48, 665; CHRYSOSTOMOU (1998), p. 25-34, ID. (2001), p. 16, fig. 3 for the inventory of dedications from the sanctuary; ID. (2008), p. 251-2.

86. снRуsostomou (1998), p. 37. I would like to thank M. Mili for discussing this point with me in 2003.

87. MILI (2005), p. 281-283; CHRYSOSTOMOU (2008).

88. IG IX 2, 575 (= Volos E786): HEINZ (1998), cat. no. A66; CHRYsostomOU (1998), p. 53-55, 104; ID. (2002), p. 204-209.

89. CHRYSOSTOMOU (1998), p. 104-112; ID. (2001); ID. (2002); ID. (2008), p. 248. GARCÍA RAMÓN - HELLY (2007), p. 278-279. For E(n)nodia Patroa in Pagasai see also: KRAVARITOU (2011), p. 18.

90. KAKAVOYIANNIS (1977), p. 126-128, plan 2, pl. 75 (Volos Museum BE 875, 876); SEG 34, 573-574; CHRYSOSTOMOU (1998), p. 62-65. According to some scholars, the three round protrusions crowning the stele Volos Museum E1308, represent round cakes offered in sacrifices to the gods: PARISINOU (2000), p. 153-154.

91. HELLY (1970); SALVIAT - VATIN (1971). Votive inscribed stelai have been found in numerous Thessalian cemeteries, at Pherai, Phthiotic Thebes, Atrax. At Atrax, some late Classical and Hellenistic stelai bearing dedications to $\mathrm{En}(\mathrm{n})$ odia and Zeus Thaulios were allegedly found in the 
periphery of the western cemetery of the city: TZIAFALIAS (1995); SEG 34, 490; AD 44 (1989), Chronika p. 237-8, no. 10 (AEM $\Lambda$ 89/16). Tziafalias has postulated the existence of a large sanctuary dedicated to Zeus Thaulios at the western extension of the city, a few hundred metres outside the western part of the fortification walls (TZIAFALIAS [1995], p. 75; ID., AD 44 [1984], Chronika p. 238 n. 19). Zeus Thaulios has often been associated with cemeteries and the world of the dead,but MILI (2005), p. 86, 93-95, 303 has shown that it is equally possible that the god could receive civic cult, as in the large sanctuary of En(n)odia at Pherai or the sanctuary at Agia Paraskevi at Pharsalos, or could have been worshipped by kinship groups; in Atrax, among the finds was an inscription bearing a dedication to Zeus Thaulios by the Simmidai, who have been identified as a familial group (SEG 51, 677bis; DECOURT - TZIAFALIAS [2001], esp. p. 147, explain the Simmidai as a religious college and not as a civic group; also CHRYsostomou (1998), p. 236, n. 918). We should bear in mind that in all these cases the inscriptions were chance finds, therefore their value in securely identifying the character and location of the cult places is limited.

92. Preliminary report in APOSTOLOPOULOU-KAKAVOYIANNI (1990); additional information in CHRYsostomou (1998), plan 2, no. 4, p. 29, 43-47, pl. 3-4. The sanctuary has not been fully published. On the cemeteries of Pherai: DOULGERI-INTZESILOGLOU (1994), p. 79; STAMATOPOULOU (1999), cat. no. 63.

93. The building walls measured: $5.35 \mathrm{~m}$ on the intact western side; the southern and northern si des were preserved to a length of $2.60 \mathrm{~m}$ and $2.50 \mathrm{~m}$ respectively. Walls survived to about $0.60 \mathrm{~m}$ in height, and were made of rough stones; their upper parts were of mud-brick. Along the inner face of the southern wall of the building was a low oblong built structure, which has been identified as a bench for the deposition of votives. Apostolopoulou-KaKavoyianni (1990), p.65, fig. 2-3; CHRYSOSTOMOU (1998), p. 45, n. 99, pl. 4. On benches: MAZARAKIS AINIAN (1997), p. 280.

94. Only a few graves have been fully investigated so far; four were Protogeometric and two Hellenistic: Apostolopoulou-KaKavoyianni (1990), p.59, fig. 2; EAD. (1992), p.313, n. 16. CHRYSOSTOMOU (1998), p. 45 has proposed that grave 3 was Early Christian; DOULGERI-INTZESILOGLOU (1994), p. 79.

95. Apostolopoulou-KaKaVOYianni (1990), fig. 3: showing the building before the removal of the upper floor level.

96. APOSTOLOPOULOU-KAKAVOYIANNI (1990), p. 60, fig. 4; CHRYSOSTOMOU (1998), p. 45-46, pl. 4a for a view of the building after the completion of the excavation (the pit was at the right hand corner of the picture), $4 \beta$ for a view of the deposit.

97. This is based on the date of the offerings. APOSTOLOPOULOU-KAKAVOYIANNI (1990), p. 62-63, has dated the sanctuary's use from the end of the 5th c. BC to the late Hellenistic period.

98. Grave 3 has been dated by the excavator to the Hellenistic period: APostolopoulouKAKAVOYIANNI (1990), p. 63; CHRYSOSTOMOU (1998), p. 45, dated the grave to the Early Christian period. 99. Volos Museum BE 1511; APOSTOLOPOULOU-KAKAVOYianNi (1990), p. 63; CHRYsostomou (1998), p. $44-$ 45 , pl. 6 a.

100. SEG $40,667$.

101. Volos Museum, BE 1628 (Pr.H.: 0.22 m). APostolopoulou-KaKavoyianni (1990), p. 60, no.3, fig. 8; CHRYSOSTOMOU (1998), p. 46, 157, pl. $4 \beta, 16 \alpha$ [classified as uncertain].

102. Kozani Collection KAMK 895: CHRYSOSTOMOU (1998), p. 74, no. 1, 151-2, pl. 14ß; HATZINIKOLAOU (2011), p. 118, 301, no. 155. On the iconography of En(n)odia: A. MOUSTAKA, s.v. Enodia, LIMC III.1 (1986), p. 743-744; CHRYSOSTOMOU (1998), p. 141-155.

103. Volos Museum BE 1624 (Pr.H.: $0.20 \mathrm{~m}$ ). APostolopoulou-KaKAVOYIANNI (1990), p. 60, 62; CHRYSOSTOMOU (1998), p. 46, pl. $13 \alpha$.

104. Volos Museum BE 1631 (H: 0.235 m): APostolopoulou-KaKAVoyianni (1990), p. 60, no. 2, fig. 7; CHRYSOSTOMOU (1998), p. 233-235, pls. $4 \beta, 34$. 
105. For the iconography of Hades and its similarities to Zeus's, cf. S.-C. DAHLINGER, S.V. Hades, LIMC IV.1 (1998), p. 367-380. For a large-scale clay head of a bearded male mature god, belonging to a herm from the Sanctuary of Demeter and Kore in Corinth: BooKIDIS (2010), 252-255, cat. no. 152, pl. 115; similarly for a satatue of a male mature god from the sanctuary of Demeter at Kyparissi in Kos: SCHIPPOREIT (2013), p. 235.

106. Volos Museum BE 1627: APOSTOLOPOULOU-KAKAVOYIANNI (1990), p.60, no. 6; CHRYSOSTOMOU (1998), p. 181-182, 235, pls $4 \beta, 34 \beta$.

107. APOSTOLOPOULOU-KAKAVOYIANNI (1990), p. 62-63; CHRYSOSTOMOU (1998), p. 233-235. For the cult of Zeus Meilichios in Thessaly: F. PFISTER, "Meilichioi Theoi”, REXV (1932), p. 339-343; H. SCHWABL, “ Zeus I. Epiklesen”,RE X A (1972), p. 335-336; SEG 37, 460; MILI (2005), p. 284-285. For Zeus Meilichios: BURKERT (1985), p. 200-201; SCULLION (1994), p. 93-94; JAMESON et al. (1993), p. 81-103, esp. 85 on Thessaly; PARKER (2005), p. 42, 424-426; KOSTAKE (2008), p. 148, 159, for shrines of Zeus Meilichios in relation to city fortifications; GROTTA (2010), esp. p. 147-175; SEIFERT (2011), p. 212-217 (Athens; children in cult).

108. HABICHT (1987), p. 273-274 on IGIX 2, 578; HEINZ (1998), cat. no. A123; SEG 24, 400 (Larisa). Also from Larisa comes a naiskos bearing a dedication to Zeus Meilichios: AD 45 (1990), Chronika p. 220 (AEM $\Lambda$ 90/43). A dedication to Zeus Meilichios by a Dionysios is preserved on a pillar that was found at Pefkakia in Demetrias (Volos E71/18), HEINZ (1998), p. 388, cat. A4.

109. PALAIOKRASSA-KOPITSA (1996), p. 229-231; EAD. (2007), p. 42, fig. 62-63. The excavator proposed that Zeus Meilichios was worshipped at Palaiopolis as protector of the dead. Similarly carved on the bedrock next to a cave was the boundary inscription to Zeus Meilichios at Goritsa ( SEG 27, 197).

110. FILIMONOS-TSOPOTOU (2004), p. 117-118, 156-163.

111. SEG 9, 325-346; FABRICOTTI (2000), p. 182; MENOZZI (2002), p. 78, fig. 10-12.

112. PARKER (1983), p.39-40, 110; JAMESON et al. (1993), p. 88-97; GROTTA (2010), p. 101-136 (epigraphic evidence from Selinus), 137-175; PATERA (2012), p. 226-230.

113. MISAELIDOU-DESPOTIDOU (1993), esp. p. 211, for the Kerdoion, Herakleion immediately inside the walls and the Heleneion that was located near a city gate.

114. Helly (1970); SALVIAT - VATIN (1971); TZIAFAlias (1997), esp. p.62; HeLly (2010), p. 62; and recently GARCÍA RAMÓN - HELLY (2012), 63-67.

115. Helly (2010), p. 62 proposes that the epiclesis should be linked to tombs; contra MILI (2005), p. 283, who links it to the protection/welfare of animals.

116. RAKATSANIS - TZIAFALIAS (1997), p. 18, 22, 38. We should also note here the discovery in the $2^{\text {nd }}$ Stelai-Tower at Demetrias of a votive relief, dedicated to Hero Enodios (Volos Museum 4414 ): ARVANitopoulos, (1910), p. 239; PuD 188, n. 2; сHRYsostomou (1998), p. 259-261, pl. 34ß. Given that most of the stones that were reused as building material for the reinforcement of the walls came from the nearby area, it is likely that the relief was set somewhere in the vicinity of the fortifications; of course this is conjectural.

117. A possible case may be the building found at Anavyssos, in Attica, in close association to the three most elaborate tombs of the Late Geometric burial ground: AD 29 (1974), Chronika p. 108110 (P. Doltsetis' plot). The building was most likely funerary in character, but its characterization as a 'chapel' by Mazarakis Ainian is exaggerated, as it depends heavily on the discovery of benches along the walls of the building: MAZARAKIS AINIAN (1997), p. 145; ID. (1999), p. 20. Recently a 'funerary' aspect has been proposed for the architectural remains discovered near the northern cemetery of Myrrinous (modern Merenda); according to the excavators the temple-like building is related to the grave enclosures discovered nearby and is contemporary to the graves: ANETAKIS et al. (2009), p. 193-4, fig. 8. One should note here the spaces among family enclosures used for commemorative rites by the relatives of the people buried in the nearby 
graves for tomb cult or for the cult of collective ancestors like the Tritopatores: KNIGGE (1988), p. 103, no. 14; JAMESON et al. (1993), p. 107-114; STROSZECK (2010).

118. AD 39 (1984), Chronika p. 148; 40 (1985), Chronika p. 196; 42 (1987), Chronika p.269; STAMATOPOULOU (1999), p. 207-208, cat. no. 54, pl. 67b. I would like to express my warmest thanks to B. Intzesiloglou for the useful information about his excavations at Prodromos and for showing me photographs of the site and finds.

119. AD 39 (1984), Chronika p. 148; 42 (1987), Chronika p. 269, pl. 157ץ [oikos $\triangle$ ].

120. AASA, Apx.Apß. 43: 8 Iouvíou 1914, with drawing. Also: MARzolfF (1980), pl. 7.3; ID. (1986), p. 82-84, fig. 3-4, n. 155; THÜNGEN (1994), p. 12, 21, 38, 138, cat. no. 118, Taf. 73.2, Beil. 50.1. According to P. Marzolff the exedra was situated very near the road and about $200 \mathrm{~m}$ from the Bourboulithra springs (pers. comm. on 5 July 2001).

121. A very interesting small rock-cut theatre-like structure set near the top of the Sanctuary of Demeter and Kore at Corinth has been linked with ritual performances: BооKIDIs (1997), p. 256257; EAD., (2009), p. 231-232; HOLLINGSHEAD (2012), p. 32-33, 48. Similarly theatral arrangements, mainly steps, have been attested at a number of sanctuary sites, allowing the active participation and observation to ritual acts: HOLLINSHEAD (2012), p. 28-30, 46-56.

122. Stamatopoulou (1999), p. 163, n. 819-820, p. 191; AVAgianou (2002); KRAVARitou (2011), p. 119; EAD. (forthcoming).

123. GRAF - JOHNSTON (2007), no. 25-29, p. 131-3; CALAME (2008); and more recently EDMONDS III (2011), various articles in the book. Also: PARKER - STAMATOPOULOU (2007); FERRARI - PRAUSCELLO (2007); SEG 55, 162 for the recently identified lamella from Pherai.

124. For example at S. Anna in Acragas; Metaponto; Taras: HINZ (1998), p. 71-72, 182-187, 216217. At numerous sites buildings or built enclosures have been excavated inside cemeteries but due to the lack of finds or the disturbance of the area it is very difficult to determine the purpose of the building. Examples include: a) the building investigated among Hellenistic graves at Myrina on Lemnos (Yiakoumas' property): ARCHONTIDOU - DELIGIORGI (1994), p. 182-189, esp. 182185, with plan and illustration on 182-3; AD 48 (1993), Chronika p. 424. b) The building in the cemetery of Thermi near Thessaloniki has been dated to the $4^{\text {th }}$ century BC while the later burials at the site are of the late Archaic period (6 Lambraki st.): ALLAMANI et al. (1999); AD 54 (1999), Chronika p. 549-543, esp. 542-3; CHRYSSANTHAKI-NAGLE (2006), p. 16 n. 52. c) The two-room building found among graves at Megara (6 Chaniou and Aigeirouson st.): AD 49 (1994), Chronika p. 57-59, pl. 25 y (A. Priskos' plot); as there were no traces of burials nor diagnostic finds, the building was tentatively identified as a pre-made grave enclosure, which was never used. d) At Pylaia Thessalonikis, near Phoinix (locality Lygaria): AD 54 (1999), Chronika p. 530-531, two buildings were found in close proximity to the graves; one did not contain diagnostic finds and the other appears to have been a farmhouse of later date than the cemetery.

125. PAPACHATZIS (1985); ID. (1981). He was in turn influenced by PHILIPPSON (1944); CHRYSOSTOMOU (1998) basically follows the same model of interpretation.

126. MORGAN (2003); MCINERNEY (1999).

127. сHRYSOSTOMOU (1998), p. 112-133.

128. Let us not forget that sanctuaries of the Nymphs were also found outside the city gates, in areas with good provision of water, as for example at Atrax, where remains of a Doric temple, destroyed by the change in the course of the river Peneios, and dedicatory inscriptions have been found in the wider area of the northern cemetery of the city. The proximity to a water source was probably the major reason for the choice of the site: TZIAFALIAS (1995), p. 73; AD 44 (1989), Chronika p. 237-8, no. 11. It is thus evident that the geographical proximity of a shrine to city gates need not always be deliberate.

129. A small temple, resembling a simple oikos in plan, with a pronaos and cella, found in 1993 at Melitaia, was dedicated according to Dakoronia to Artemis-Aspalis. A statue base bearing a votive 
dedication to En(n)odia was among the finds: DAKORONIA (2001); EAD. AD 48 (1993), Chronika p. 21; SEG 52, 560; GARCíA RAMÓN - HELLy (2007), p. 292; CHRYSOSTOMOU (2008), plan 1 on p. 246, and 254255; STAVROGIANNIS (2010), p. 587-590.

130. GARCíA RAMÓN - Helly (2007), p. 289-291; PARKER (2005c), on double cultic epithets and their significance.

131. Pingiatoglou (1981), p. 98-113; DILLON (2002), p. 234-235; COLE (2004), p. 209-218; VERNANT (1991), p. 198-202; MORIZOT (2010), focusing on childbirth; PARKER (2005), p. 231-232, 242-245, 431, 439-442; SEIFERT (2011), p. 145-155, 199-201, 238-239 (with earlier bibliography); HATZOPOULOS (2006), p. 55 (Macedonia); solima (2011), p. 221-228 (for the Peloponnese); QUANTIN (2010), p. 434 for Apollonia in Epirus. Also CALAME (2001), p. 91-101, esp. 100-101 for female rituals of Artemis and their importance for adolescent girls.

132. HEINZ (1998), p. 58-63, 409 no. A52 for the limestone base from Pherai bearing the dedication of Kytheria to Artemis with the formula tropheia ton teknon; DECOURT - TZIAFALIAS (2009), esp. p. 464 on an unpublished long inscription of the mid-2nd century BC, found at Marmariani, that preserves a lex sacra, where Artemis Phylake is mentioned among other deities, some of eastern origin. They assume that the cult was initiatory in character with at least some of the rituals being nocturnal.

133. ARVANItopoulos (1911), p. 317-320, fig. 7; ID. (1916), p. 31-32; HELly (1973 (i)), p. 31, 148-149; ID. 1973 (ii), nos. 168-196; HEINZ (1998), cat. nos. 132-156, A61 (Eileithyia, with various spellings), 158 (Eulochia), 159 (Eyonymos), 160-165 (Geneteira), 170 (Lochia); pingiatoglou (1981), p. 107111; RAKATSANIS - TZIAFALIAS (2004), p. 28-32; WISE (2007), p. 58-59, 80-81, 229-231. See also PARKER (2005C), p. 223-226 for the meaning of the double epithet, Artemis Eileithyia.

134. Pingiatoglou (1981), p. 112; HABICHT (1987), p. 314 (Larisa); HeINZ (1998), cat. nos. 167-169; G UARISCO (2001), p. 84.

135. HEINZ (1998), cat. nos. 129-130 (Larisa), 157 (Pythion).

136. HATZOPOULOS (1994), p. 25-40; ID. (2006), p. 55-56; GARCíA RAMÓN - HELlY 2007, p. 291-2, who also stress the reference to Artemis Pagasites at Larisa with the term nebeusasa; contra GRANINGER (2007) (but see the criticism by Helly, BE 2008, p.674-675, no. 297); SEG 52, 496. See also: RAKATSANIS - TZIAFALIAS (1997), p. 25-27, 62-63, 67; HEINZ (1998), p. 21-22, 24, 62-63, cat. nos. 118, 120-122, 174-176, A65; GUARISCO (2001), p. 84; CHRYSOSTOMOU (2001), p. 12, n. 8; FARAONE (2003), p. 58-59; MILI (2005), p. 98-100, on a balanced discussion of the complex rituals associated with the cult of Artemis Throsia.

137. Echinos relief: Archaeological Museum of Lamia, AE 1041: DAKORONIA - GOUNAROPOULOU (1992); HEINZ (1998), p. 230, cat. 107, fig. 252; COLE (2004), p. 213; MORIZOT (2004), p. 160-166; KLÖCKNER (2006), p. 140-143; WISE (2007), p. 201-204; GARCÍA RAMÓN - HELLY (2007), p. 290.

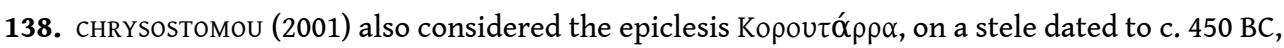
as indicative of En(n)odia as patron of children. Contra: SEG 51, 739, where Chaniotis proposes

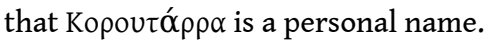

139. GARCíA RAMÓN - HELLY (2007), esp. p. 287-288, see the deity as responsible for the raising and protection of infancy and young children (rather than strictly protecting childbirth or the passage from childhood to puberty). СнRуsоsтомоu (2002), 204-209, sees En(n)odia Strogika Patroa in Larisa as a kourotrophic deity. He gives the same meaning to En(n)odia Stathmiabased on the formula of the dedication, for the well-being of a child (IG IX 2, 577), but also for En(n)odia Fastika (IG IX 2, 575; SEG 35, 590. Both stelai were found in Larisa and have been dated in the third quarter of the $5^{\text {th }}$ century BC on the basis of letter forms: RAKATSANIS - TZIAFALIAS (1997), p. 47. According to Chaniotis, in SEG 49, 622, the epithet $\Sigma \tau \rho o \gamma i k \alpha$, should be seen as the loving, affectionate'. See however the recent article by GARCíA RAMÓN - HELLY (2012), p. 57-63 where they argue that stropika instead of strogika should be read on the stone. 
140. This was also hinted recently by GARCíA RAMÓN - HELLY (2007), p. 287 and esp. 293-294; also MILI (2005), p. 284-285.

141. The absence of specific formulas in the dedicatory inscriptions or of diagnostic finds, except for the single kourotrophic figurine, does not allow us to determine whether the deity was concerned with specific stages of children's lives. But it is worth noting the interest in Demetrias in childbirth as is evidenced by the unique iconographic type of the Artitokos, for example in the stele of Hediste (Volos L1) with its moving epigram: PEEK (1955), p. 481 no. 1606; Cairon (2009), p. 260-262, no. 85. See also PEEK (1955-57), p. 434 no. 1462; CAIRON (2009), p. 274-278, no. 92, the epigram for Potala found in the eastern cemetery of Larisa.

142. MULLER, TARTARI - TOÇI (2010), esp. p. 399-400, for the interpretation of the cult.

143. HUYSECOM-HAXHI - MUKA (2010).

144. TATARLI et al. (2010); SHEHI - TICHIT (2010).

145. MULLER, TATARLI - TOÇI (2004), esp. p. 620 for the identification; Also: TATARLI et al. (2010).

146. COLE (2004), p. 180-194, esp. 185; VERNANT (1991), p. 197-8.

147. PARKER (1996), p. 127, n. 21, 340; ID. 2005, p. 46, 57, fig. 4 on p. 53; GUARISCO (2001), p. 77; WISE (2007), p. 36, n. 100, p. 66; KOSTAKe (2008), p. 148, 159; zOGRAFOU (2010), p. 105.

148. MARTIN (1944-45); GRANDJEAN - SALVIAT (2000), p. 58, fig. 17; KOZELJ - SGOUROU - WURCH-KOZELJ (2005), p. 18; ZOGRAFOU (2010), p. 102. Moreover, one of the gates bore the inscription: Artemidos Epaulies Hekates (IG XII 8, 359). COLE (2004), p. 50-57, for a discussion of the significance of the sculptural decoration at the gates of the Thasian city walls.

149. MULLER - TATARI - TOÇI (2004), esp. p. 620 for the identification. At Araxos in the Peloponnese, Artemis was worshipped along with other deities at a built altar, in front of the main gate of the Dymnaian Wall: AD 19, (1964) Chronika p. 187-188; BRULOTTE (2002), p. 181; SOLIMA (2011), p. 22.

150. VERNANT (1991), p. 204, repeated in Parker (2011), p. 90-91.

151. PARKER (2005), p. 414-415. See other gods and heroes bearing epithets that could denote an association with gates: like Herakles Propylaios in Kozani (mid-2 ${ }^{\text {nd }}$ century BC: EAM 4; ILIADOU 1998, p. 76-78), Herakles Empyleios at Onchestos, SCHACHTER (1986), p. 217; perhaps Dionysos Parabolos at Byzantion, SEG 50, 665; Artemis Prothyraia at Epidauros (IG IV $2,1,276: 3^{\text {rd }}$ century BC), Pergamon (mid-2 $2^{\text {nd }}$ century AD: IvP III 161A, 161B).

152. ZOGRAFOU (2010), p. 93-109.

153. Examples include: a) Amphipolis, locality Koukles, where a large deposit and niches containing mainly figurines of the Late Hellenistic period was found very near the southern wall of the fortification tower, in the cemetery area. The finds suggest cult of Cybele, Attis, Harpokrates: LAZARIDIS (1981), esp. p. 22-24. b) Abdera: where a hypaethral sanctuary of a female deity was found on the level of the outer face of the euthenteria of city walls, with built escharas, a very large number of figurines and 2000 miniature hydriai, animal bones, etc, that can be dated from the $6^{\text {th }}$ to the early $4^{\text {th }}$ centuries BC: KOUKOULI-CHRYSANTHAKI (1987); EAD. (1997), p. 720. c) Ambrakia: at the foundation level of the early phase of the fortification wall was a paved walled enclosure that had two building phases. The Hellenistic one contained elaborate bull figurines: AD 52 (1997), Chronika p. 564-566, (Mostraion, Ag. Paraskevis st, no. 176); d) Gortys in Arcadia, near Gate C of the fortifications: JOST (1985), p. 205, proposed that the shrine by the Gate C, was dedicated to Artemis; MARTIN - METZGER (1940-1941), p. 278-282; MARTIN (1947-1948), esp. p. 105112 saw it as a sanctuary of Pan, whereas MELFI (2007), p. 213-216, 221-225, linked it to Asklepios; e) Leontinoi: immediately outside the southern gate of the ancient city: UHLENBROCK (1998), p. 312; f) Acragas, S. Anna: the shrine was immediately outside the city gates: HINZ (1998), p. 71; g) Megara Hyblaia, Fundstelle $\mathrm{C}$, was found at the northeast corner of the fortification wall; it was a large sacred zone already in the Archaic period: HINZ (1998), p. 141-142. h) See also the niche by 
the eastern gate of Rhamnous, which Petrakos supposed that was for an image of cybele and above it a dedication to Demeter and Kore: PETRAKOs (1999), vol. I, p. 67-69.

154. UHLENBRoCK (1988), p. 154-155; LE DiNAHET (1984); HINZ (1998), esp. p. 50, 71 (Sanctuary of S. Anna at Acragas), 202-209 (Locri, sanctuaries at Contrada Manella, Contrada Parapezza and Grotta Caruso); CARTER (1994); COLE (1994); PATERA (2012), p. 216-225. For the location of sanctuaries of Demeter and Kore in Ionia: SCHIPPOREIT (2013), p. 245-250.

155. The same has been recently proposed for the Artemision at Epidamnos/Dyrrhachion: ELLINGER (2010), esp. p. 475.

156. KOSTAKE (2008), esp. p. 159; see also COLE (2004), p. 182-184 for Artemis' sanctuaries near thoroughfares.

157. Paus., II, 18, 3 (Argos), II, 5, 4 (Corinth): Pingiatoglou (1981), p. 38-39. PARKER (2005), p. 56 comments on the tendency to locate shrines of birth goddesses outside city walls.

158. In the case of the Dion sanctuary, its relation to the fortification walls may be fortuitous, given its early date and therefore the proximity to water was more relevant. For the kourotrophic elements of the cult of Demeter at Dion see PINGIATOGLou (2010), esp. p. 211-214. On the kourotrophic elements of Demeter's cult (with emphasis on the Sanctuary of Demeter and Kore at Corinth): BOOKIDIS (2010), p. 268-276; MERKER (2000), p. 334-341.

159. Soros: MAZARAKIS AINIAN (2011), esp. p. 11-13; LEVENDI (2009). GARCíA RAMÓN - HELLY (2007), p. 292, 294-5 stress that at Pagasai both Apollo and Artemis Pagasites were divinities with strong kourotrophic functions. On the cult of Apollo at Pythion in Perrhaibia and the dedication for the well being of children, ibid., p. 295, n. 81.

\section{ABSTRACTS}

Archaeological and epigraphical evidence suggests that cult places existed near or within Thessalian cemeteries of the Classical and Hellenistic periods. Some, especially at Pherai and Demetrias, have been characterized by scholars as 'funerary' because of their location within a burial ground, and because of the supposed 'chthonian' nature' of the venerated deities. This paper will focus on the so-called Pasikrata sanctuary at Demetrias, situated in the southern cemetery of the city, and investigated by A.S. Arvanitopoulos between 1912-1915 under the auspices of the Archaeological Society of Athens. Alongside the presentation of the evidence, which is based on the study of the archival material and of a large part of the finds, the focus will be on the discussion of the location of the sanctuary, the type/character of the finds, the nature of the venerated deities and the re-interpretation of the suburban sanctuaries of Thessaly.

Des témoignages archéologiques et épigraphiques suggèrent que des lieux de culte existaient tout près de cimetières, ou même au milieu d'entre eux, en Thessalie aux périodes classique et hellénistique. Certains d'entre eux, spécialement à Phères et à Démétrias, ont été qualifiés de «funéraires» en raison de leur localisation dans un espace d'inhumation et de la prétendue nature «chthonienne" des divinités honorées. Cet article se concentre sur ledit sanctuaire de Pasikrata à Démétrias, situé au sud de la nécropole de la cité et fouillé par A.S. Arvanitopoulos entre 1912 et 1915 sous les auspices de la Société archéologique d'Athènes. Parallèlement à la présentation de la documentation, qui est fondée sur l'étude des archives et d'une grande partie des trouvailles, l'attention sera portée sur la location du sanctuaire, le type d'artéfacts mis au 
jour, la nature des divinités honorées et la réinterprétation des sanctuaires suburbains de Thessalie.

\section{AUTHOR}

MARIA STAMATOPOULOU

Faculty of Classics

University of Oxford

maria.stamatopoulou@lincoln.ox.ac.uk 